\title{
Signal pathways JNK and NF-KB, identified by global gene expression profiling, are involved in regulation of TNFa-induced mPGES-1 and COX-2 expression in gingival fibroblasts
}

\author{
Tove Båge*1, Johan Lindberg², Joakim Lundeberg², Thomas Modéer¹ and Tülay Yucel-Lindberg¹
}

\begin{abstract}
Background: Prostaglandin $\mathrm{E}_{2}\left(\mathrm{PGE}_{2}\right)$ is involved in several chronic inflammatory diseases including periodontitis, which causes loss of the gingival tissue and alveolar bone supporting the teeth. We have previously shown that tumor necrosis factor a (TNFa) induces $\mathrm{PGE}_{2}$ synthesis in gingival fibroblasts. In this study we aimed to investigate the global gene expression profile of TNFa-stimulated primary human gingival fibroblasts, focusing on signal pathways related to the $P \mathrm{PE}_{2}$-synthesizing enzymes prostaglandin $\mathrm{E}$ synthases (PGES), as well as the upstream enzyme cyclooxygenase-2 (COX-2) and $P G E_{2}$ production.

Results: Microarray and western blot analyses showed that the mRNA and protein expression of the inflammatory induced microsomal prostaglandin E synthase-1 (mPGES-1) was up-regulated by the cytokine TNFa, accompanied by enhanced expression of COX-2 and increased production of $\mathrm{PGE}_{2}$. In contrast, the expression of the isoenzymes microsomal prostaglandin E synthase-2 (mPGES-2) and cytosolic prostaglandin E synthase (CPGES) was unaffected by TNFa treatment. Using oligonucleotide microarray analysis in a time-course factorial design including time points 1, 3 and $6 \mathrm{~h}$, differentially expressed genes in response to TNFa treatment were identified. Enrichment analysis of microarray data indicated two positively regulated signal transduction pathways: c-Jun N-terminal kinase (JNK) and Nuclear Factor-KB (NF-KB). To evaluate their involvement in the regulation of mPGES-1 and COX-2 expression, we used specific inhibitors as well as phosphorylation analysis. Phosphorylation analysis of JNK (T183/Y185) and NF-kB p65 (S536) showed increased phosphorylation in response to TNFa treatment, which was decreased by specific inhibitors of JNK (SP600125) and NF-KB (Bay 11-7082, Ro 106-9920). Inhibitors of JNK and NF-KB also decreased the TNFastimulated up-regulation of mPGES-1 and COX-2 as well as $\mathrm{PGE}_{2}$ production.

Conclusion: In the global gene expression profile, the enrichment analysis of microarray data identified the two signal transduction pathways JNK and NF-KB as positively regulated by the cytokine TNFa. Inhibition of these TNFa-activated signal pathways reduced the expression of MPGES-1 and COX-2 as well as their end product PGE $E_{2}$ in gingival fibroblasts. The involvement of the signal pathways JNK and NF-KB in the regulation of $\mathrm{PGE}_{2}$ induced by TNFa may suggest these two pathways as possible attractive targets in the chronic inflammatory disease periodontitis.
\end{abstract}

\section{Background}

The chronic inflammatory disease periodontitis is characterized by tissue and bone destruction. The current concept of the etiology of periodontitis is that bacterial

* Correspondence: tove.bage@ki.se

1 Division of Pediatric Dentistry, Department of Dental Medicine, Karolinska Institutet, Huddinge, Sweden

Full list of author information is available at the end of the article components of the biofilm initiate the inflammatory cascade, including infiltration of immune cells and production of inflammatory mediators in the periodontal tissue. The initial inflammation, gingivitis, may then develop into a chronic inflammatory state of the gingiva causing destruction of the gingival tissue as well as the alveolar 
bone resulting in decreased support for the teeth, and ultimately tooth loss [1-3].

Among inflammatory mediators involved in periodontitis, prostaglandin $\mathrm{E}_{2}\left(\mathrm{PGE}_{2}\right)$ has been associated with periodontitis as a potent stimulator of bone resorption, and increased $\mathrm{PGE}_{2}$ levels have been reported in gingival tissue and gingival fluid from patients with periodontitis [4-9]. Moreover, administration of nonsteroidal antiinflammatory drugs (NSAID), inhibitors of $\mathrm{PGE}_{2}$ production, has been shown to reduce the progression of alveolar bone resorption in patients with periodontitis, implying that $\mathrm{PGE}_{2}$ is a key mediator in the pathogenesis of periodontal disease [10,11].

The proinflammatory cytokine TNF $\alpha$ is also reported to play an important part in the pathogenesis of periodontitis [12,13]. For instance, it has been shown that attachment loss is decreased in periodontitis patients after anti-TNF treatment, and subcutaneous administration of recombinant TNF $\alpha$ is demonstrated to exacerbate experimental periodontitis in rats $[14,15]$. Also, the chronic inflammatory condition rheumatoid arthritis, which shares many characteristics with periodontitis, has been successfully treated using TNF $\alpha$ blockers, further highlighting TNFa as a key inflammatory mediator in chronic inflammatory conditions [16-18]. We have previously shown that TNF $\alpha$ enhances the production of $\mathrm{PGE}_{2}$ in gingival fibroblasts, but the intracellular signal pathways regulating $\mathrm{PGE}_{2}$ production and $\mathrm{PGE}_{2}$-synthesizing enzymes have still not been completely elucidated $[4,19]$.

The biosynthesis of $\mathrm{PGE}_{2}$ from membrane lipids is catalyzed by three groups of enzymes acting sequentially. First, phospholipase $\mathrm{A}_{2}$ converts membrane lipids to arachidonic acid [20,21]. The cyclooxygenases (COX-1 and COX-2) then convert arachidonic acid to prostaglandin $\mathrm{H}_{2}$ [22]. Finally, the third and most recently identified group of isoenzymes is the prostaglandin $\mathrm{E}$ synthases (PGE synthases) which catalyze the conversion of COXderived prostaglandin $\mathrm{H}_{2}$ to $\mathrm{PGE}_{2}[23,24]$. Up to date, three PGE synthases have been described: The microsomal and inducible mPGES-1, the constitutively expressed cytosolic cPGES and the most recently discovered microsomal mPGES-2 [25-29]. We have previously reported that mPGES- 1 and COX-2 are up-regulated by TNF $\alpha$ and IL- $1 \beta$ in gingival fibroblasts $[4,30,31]$.

The inflammatory mediator $\mathrm{PGE}_{2}$ as well as the $\mathrm{PGE}_{2}$ regulatory enzymes COX-2 and mPGES- 1 have been shown to be up-regulated by inflammatory stimuli such as lipopolysaccharides, IL-1 $\beta$ and TNF $\alpha$ also in other cell types, including gastric fibroblasts, synovial fibroblasts, cardiac fibroblasts and gastric cancer cell lines [32-37]. Various intracellular signaling pathways have been reported to be involved in inflammatory-induced $\mathrm{PGE}_{2}$ production and in the expression of $\mathrm{PGE}_{2}$-sythesizing enzymes, although these pathways seem to be both celland stimulus-specific. For example, in gingival fibroblasts, we have previously reported that the signal pathways PKC and p38 mitogen-activated protein kinase are involved in the regulation of the cytokine-induced COX2 expression but not in the regulation of mPGES-1 expression [19]. In contrast, these two signal pathways are demonstrated to be involved in cytokine-induced mPGES-1 expression in colonocytes and orbital fibroblasts $[19,38,39]$. The differences between cell types and between stimuli make it imperative to study the intracellular regulation of mPGES-1 as well as COX-2 using a cell type and stimulus which is relevant to the disease of interest. In periodontal tissue, the most ubiquitous residential cells are gingival fibroblasts. These cells, by producing inflammatory mediators such as cytokines, prostaglandins and proteolytic enzymes, participate in the inflammatory response and contribute to disease persistence [40-44].

In this work, we therefore aim to explore the signal transduction pathways involved in the regulation of $\mathrm{PGE}_{2}$-regulating enzymes mPGES- 1 and COX-2 in TNF $\alpha$-stimulated primary gingival fibroblasts through a global gene expression approach, using microarray technology. Our results show that the intracellular signal transduction pathways JNK and NF-kB are involved in the regulation of TNF $\alpha$-induced $\mathrm{mPGES}-1$ and COX-2 expression, as well as $\mathrm{PGE}_{2}$ production, in gingival fibroblasts.

\section{Results \\ Effect of TNFa on protein expression of PGE synthases and COX-2 and production of $\mathrm{PGE}_{2}$}

We have previously reported that the inflammatory mediator TNF $\alpha$ stimulates $\mathrm{PGE}_{2}$ production via the enzymes mPGES-1 and COX-2. In this study we aimed to investigate the signal transduction pathways involved in the regulation of mPGES-1, COX-2 and $\mathrm{PGE}_{2}$ in TNF $\alpha$ stimulated gingival fibroblasts through global gene expression analysis. In agreement with our previous studies $[4,30,31]$, the protein expression of mPGES- 1 and COX-2 was up-regulated by the inflammatory mediator TNF $\alpha(20 \mathrm{ng} / \mathrm{ml})$, as demonstrated by western blot analysis (Figure 1A). The time-course analysis, using time points 1, 3, 6 and $24 \mathrm{~h}$, revealed that the stimulatory effect of TNF $\alpha$ was strongest at the $24 \mathrm{~h}$ time point both for mPGES-1 and COX-2. When comparing these two enzymes, mPGES-1 expression increased starting from the $6 \mathrm{~h}$ time point, whereas COX-2 expression timedependently increased starting from the $1 \mathrm{~h}$ time point in response to TNF $\alpha$ stimulation. The expression of COX-2 also increased in cells not stimulated with TNF $\alpha$ in $24 \mathrm{~h}$ 


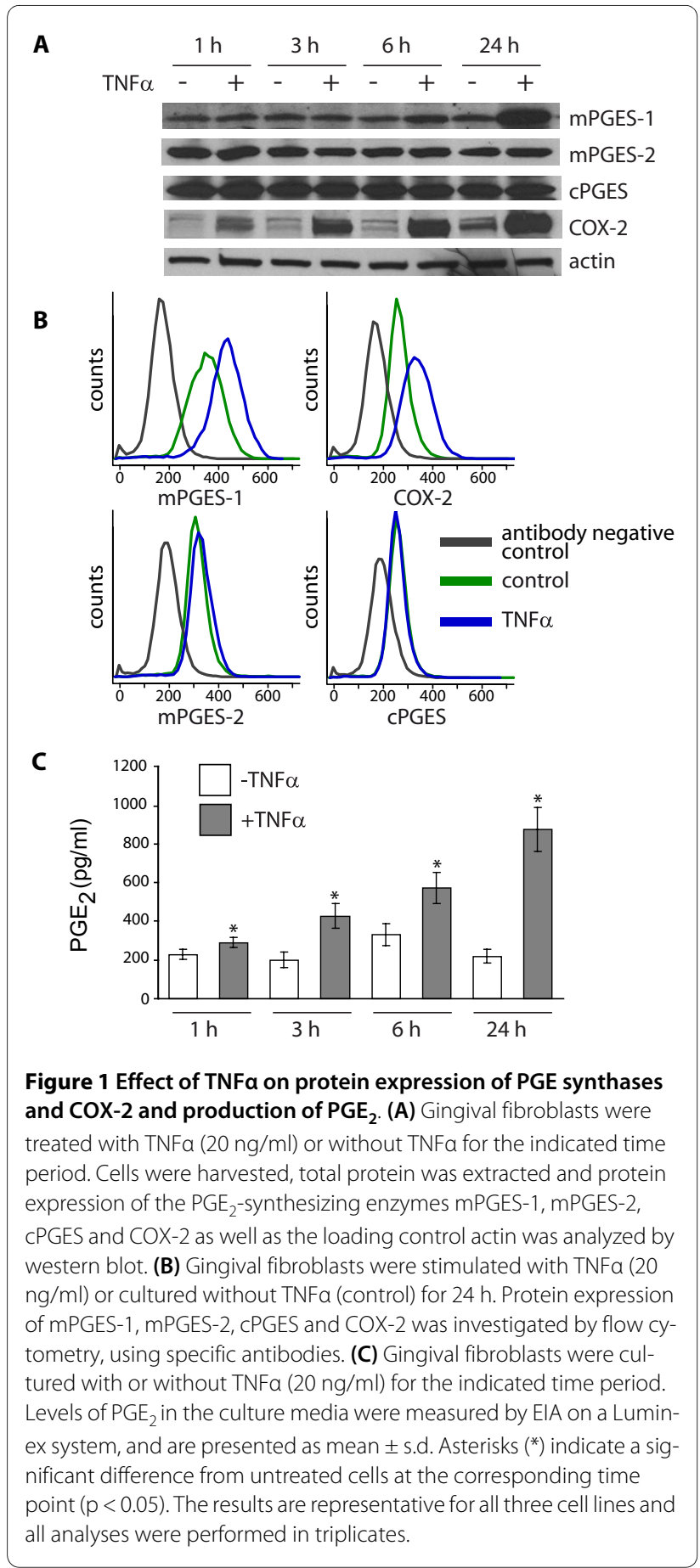

cultures, as compared to earlier time points. In contrast to mPGES-1 and COX-2, the expression of the PGE synthase isoenzymes mPGES-2 and cPGES was not affected by TNF $\alpha$ in gingival fibroblasts (Figure 1A). The western blot results were also confirmed by flow cytometric analysis, revealing an up-regulation of mPGES-1 and COX-2 expression in $24 \mathrm{~h}$ cultures of TNF $\alpha$-treated cells in contrast to mPGES-2 and cPGES expression (Figure 1B). Moreover, the induction of mPGES-1 and COX-2 expres- sion, in response to TNF $\alpha$, resulted in a time-dependent increase of $\mathrm{PGE}_{2}$ production, as shown in Figure 1C.

\section{Effect of TNFa on mRNA expression of PGE synthases and COX-2}

The mRNA expression of mPGES-1, mPGES-2, cPGES and $\mathrm{COX}-2$, as measured by oligonucleotide microarray, is seen in Figure 2. The expression of mPGES-1 as well as COX-2 was significantly up-regulated in response to TNF $\alpha$ treatment at the time points indicated $(1,3$ and 6 h). On the contrary, the PGE synthase isoenzymes mPGES- 2 and CPGES were not differentially expressed at the above-mentioned time points (Figure 2), which is consistent with the protein expression results. The microarray used in this study contained two different probes both for the mPGES-1 and cPGES genes, localized to distinct parts of each mRNA transcript. These probes resulted in similar results, and data from both probes was used in the subsequent analysis.

\section{Differential expression between TNFa-treated cells and control cells}

In the microarray analysis, the mRNA samples from 1,3 and $6 \mathrm{~h}$ cultures were hybridized according to the experimental design illustrated in Figure 3A. We used a timecourse factorial design, which facilitated identification of the genes that were differentially regulated between the time points due to TNF $\alpha$ treatment with optimal statistical efficiency [45]. This design was repeated for all three cell lines included in the study. The majority of the genes

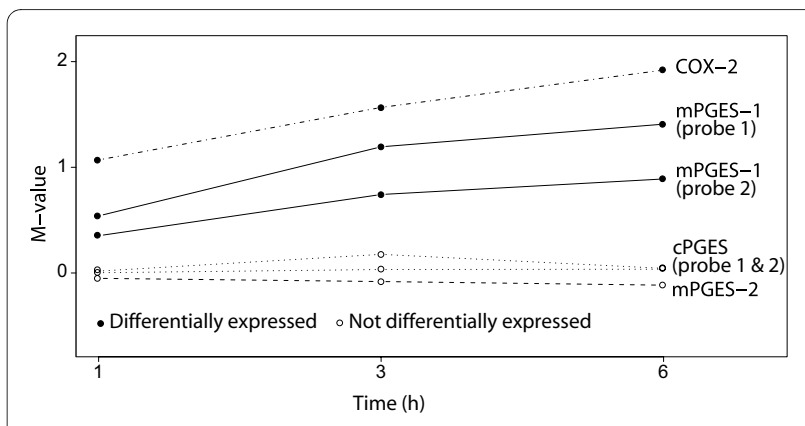

Figure 2 Effect of TNFa on mRNA expression of PGE synthases and COX-2. Gingival fibroblasts were treated with TNFa $(20 \mathrm{ng} / \mathrm{ml})$ or without TNFa for the indicated time period. Total RNA was extracted from gingival fibroblasts, and mRNA expression of the $\mathrm{PGE}_{2}$ synthesizing enzymes mPGES-1, mPGES-2, CPGES and COX-2, was measured by microarray analysis, using specific probes for each enzyme. Two probes for each of the PGE synthase isoenzymes mPGES-1 and cPGES were present on the chip used in the microarray analysis. The $y$-axis displays the M-value which is the $\log _{2}$ of the ratio gene expression of

TNFa treated cells/gene expression of control cells. A positive number corresponds to higher expression in the TNFa treated cells. The $x$-axis corresponds to the different time points. A filled circle denotes a significant differentially expressed gene at the indicated time point whereas an empty circle denotes no significant difference. 




that were significantly differentially expressed (differential expression defined as a false discovery rate $<0.05$ ) were up-regulated in the TNF $\alpha$-treated cells, which is illustrated in the volcano plots in Figure 3B-D. A positive $\mathrm{M}$-value denotes genes up-regulated by TNF $\alpha$ whereas down-regulated genes have a negative M-value. The results showed that 1157 genes were differentially expressed between the TNF $\alpha$-treated and control fibroblasts after $1 \mathrm{~h}$ incubation (Figure 3B). In the comparison between $1 \mathrm{~h}$ and $3 \mathrm{~h}, 796$ differentially expressed genes were found (Figure 3C), and 553 genes were differentially expressed between $3 \mathrm{~h}$ and $6 \mathrm{~h}$ (Figure 3D).

\section{Gene Ontology analysis of differentially expressed genes}

Enrichment analysis was performed to identify overrepresented gene ontology (GO) categories among the dif- ferentially expressed genes in the different comparisons. The gene ontology categories represent classes of genes in which more of the individual genes, included in the particular class, are differentially expressed in this data set than would be expected by a random distribution of differentially expressed genes. Complete lists of differentially expressed genes and significant GO categories are presented in the additional material (Additional files 1, 2, $3,4,5,6,7,8$ and 9 ).

The analysis of the differentially expressed genes at time point $1 \mathrm{~h}$ gave a GO profile indicative of TNF $\alpha$ involvement, where significant categories were immune response, regulation, and apoptosis related (Additional file 2). The same types of categories were also significant due to TNF $\alpha$-treatment between the $1 \mathrm{~h}$ and $3 \mathrm{~h}$ time points, signifying that genes annotated to those categories were actively regulated between $1 \mathrm{~h}$ and $3 \mathrm{~h}$ (Figure 4, for a complete list see Additional file 5). Interestingly, positive regulation of two distinct signaling pathways, "positive regulation of I-kappaB kinase/NF-kappaB cascade" and "positive regulation of JNK cascade", was identified by the enrichment analysis in the comparison of $1 \mathrm{~h}$ and $3 \mathrm{~h}$ of TNF $\alpha$ treatment, as demonstrated in Figure 4. The differentially expressed genes included in these two GO categories are listed in Table 1, together with the genes of the $\mathrm{PGE}_{2}$-synthesizing enzymes PGE synthases and COX-2 for comparison of M-values, fold changes and $\mathrm{p}$ values. For instance, in the category "positive regulation of I-kappaB kinase/NF-kappaB cascade", the gene for inhibitor of kappa light polypeptide gene enhancer in Bcells, kinase epsilon (IKBKE), which stimulates the dissociation of NF-KB and its inhibitor [46], was found to be up-regulated by TNF $\alpha$ treatment (Table 1). Furthermore, the comparison of $1 \mathrm{~h}$ to $6 \mathrm{~h}$ gene expression results showing $\mathrm{M}$-values, fold changes and $\mathrm{p}$ values for PGE synthases and COX-2 are presented in Table 2.

When comparing the $3 \mathrm{~h}$ and $6 \mathrm{~h}$ time points, fewer GO categories were significant than for the $1 \mathrm{~h}$ as well as $1 \mathrm{~h}$ to $3 \mathrm{~h}$ comparisons $(26$ terms for $1 \mathrm{~h}, 29$ terms for $1 \mathrm{~h}$ to 3 $\mathrm{h}$ and 10 terms for $3 \mathrm{~h}$ to $6 \mathrm{~h}$, see Additional files 2, 5 and 8 ). Of the two positively regulated signal cascades found in the $1 \mathrm{~h}$ to $3 \mathrm{~h}$ comparison, only "positive regulation of I-kappaB kinase/NF-kappaB cascade" was significantly changed between $3 \mathrm{~h}$ and $6 \mathrm{~h}$. Other significant categories between $3 \mathrm{~h}$ and $6 \mathrm{~h}$ were mainly immune related (see additional file 8). For the three cell lines used, differential expression of the genes included in the GO categories "positive regulation of JNK cascade" and "positive regulation of I-kappaB kinase/NF-kappaB cascade" in the $1 \mathrm{~h}$ to $3 \mathrm{~h}$ comparison is also displayed in a heat map in Figure 5.

Since the focus of this study was on signal transduction pathways, we proceeded to further explore the potential role of the two positively regulated intracellular signaling pathways NF- $\mathrm{KB}$ and JNK, identified in the $1 \mathrm{~h}$ to $3 \mathrm{~h}$ 


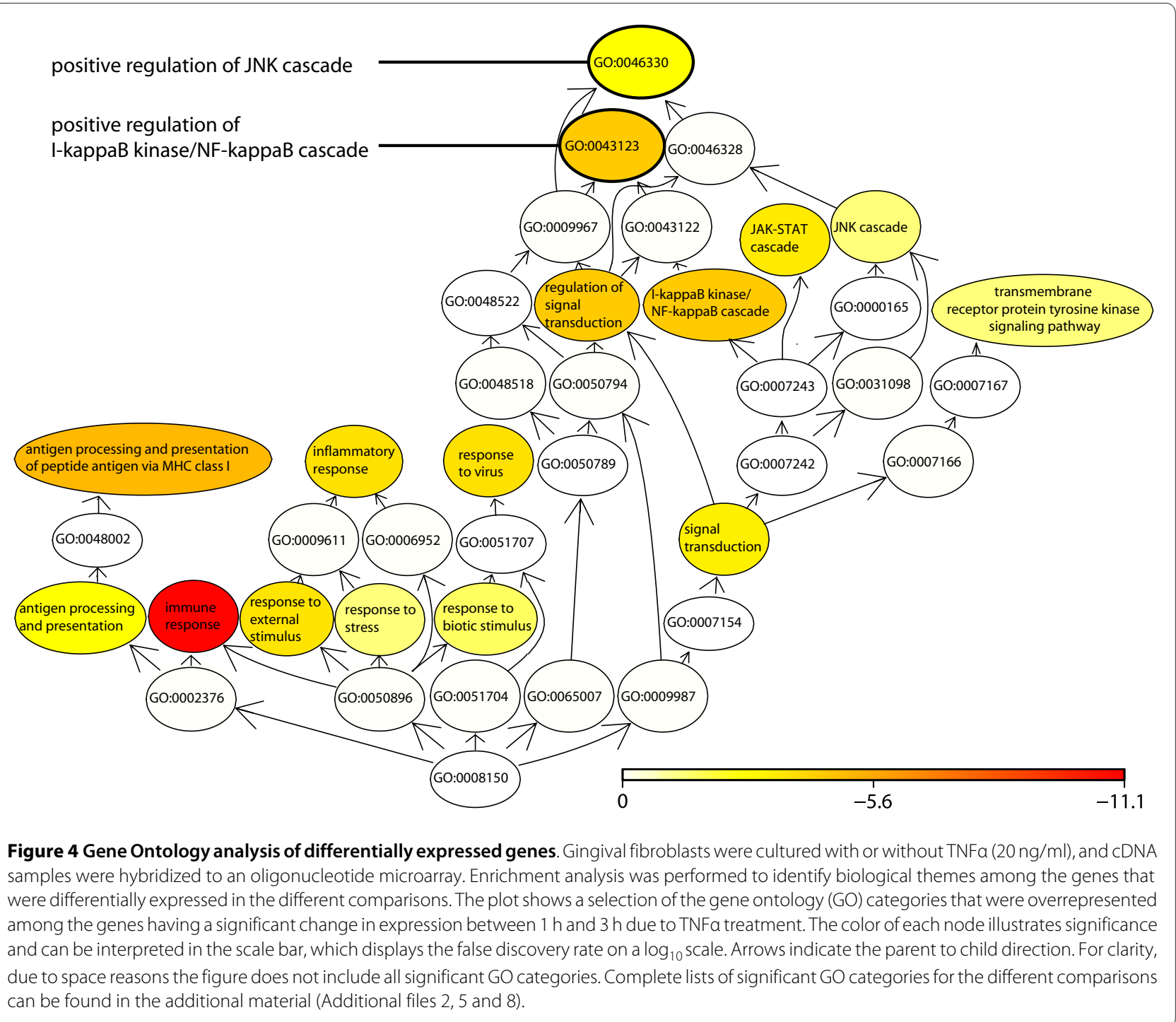

comparison, in the regulation of TNF $\alpha$-induced mPGES1 and COX-2 expression. For this purpose, we investigated the effect of specific inhibitors of the JNK and NF$\mathrm{KB}$ signal pathways on the expression of mPGES-1 and COX-2 as well as on the phosphorylation of these two pathways.

\section{Involvement of JNK in the regulation of MPGES-1 and COX-2}

To investigate the involvement of the JNK signal pathway in TNF $\alpha$-induced mPGES-1 and COX-2 expression and $\mathrm{PGE}_{2}$ production, gingival fibroblasts were treated with the specific JNK inhibitor SP600125 (SP) [47]. Treatment of the cells with SP $(10 \mu \mathrm{M})$ together with TNF $\alpha$ decreased the protein expression of both mPGES-1 and COX-2, the latter to a higher extent, in $24 \mathrm{~h}$ cultures compared to cells treated with TNF $\alpha$ only, as demonstrated by flow cytometric analysis in Figure 6A. In addition, SP also decreased mPGES-1 expression in control cells (Fig- ure 6A). To confirm the effect of SP, JNK phosphorylation analysis was performed in 1, 3, 6 and $24 \mathrm{~h}$ cultures of fibroblasts stimulated with TNF $\alpha$ in the presence of SP $(10 \mu \mathrm{M})$ as shown in Figure 6B. The results, expressed as phosphorylated JNK ( $\mathrm{p}$-JNK) relative to control cells at 1 $\mathrm{h}$, showed a peak in $\mathrm{p}-\mathrm{JNK}$ at $3 \mathrm{~h}$ of incubation, as compared to unstimulated control cells (Figure 6B). The TNF $\alpha$-stimulated levels of p-JNK significantly decreased in the presence of SP $(10 \mu \mathrm{M})$, compared to cells treated with TNF $\alpha$ only, at all time points studied (Figure 6B). Furthermore, the effect of SP on p-JNK was also investigated at an earlier time point, 10 minutes after stimulation (Figure 6C). The results, expressed as phosphorylated JNK (p-JNK) relative to control cells at the start of incubation, showed that the TNF $\alpha$-stimulated level of p-JNK was decreased to control levels in the presence of SP (Figure 6C). Concurrent with the protein expression results of mPGES-1, the inhibitor $(5-20 \mu \mathrm{M})$ 
Table 1: $\mathrm{PGE}_{2}$-synthesizing enzymes and differentially expressed genes in selected significant GO categories (1-3 h).

\begin{tabular}{|c|c|c|c|c|}
\hline Symbol & Gene Name & M-valuea & Fold Change & p value \\
\hline \multicolumn{5}{|c|}{$P G E_{2}$-synthesizing enzymes } \\
\hline PTGES & microsomal prostaglandin E synthase-1 (probe 1) & 0.65 & 1.6 & $2.4 \times 10^{-4}$ \\
\hline PTGES & microsomal prostaglandin E synthase-1 (probe 2) & 0.39 & 1.3 & $0.09^{b}$ \\
\hline PTGES2 & microsomal prostaglandin E synthase-2 & -0.03 & 1.0 & $1.00^{\mathrm{b}}$ \\
\hline PTGES3 & cytosolic prostaglandin E synthase (probe 1) & 0.03 & 1.0 & $1.00^{\mathrm{b}}$ \\
\hline PTGES3 & cytosolic prostaglandin E synthase (probe 2) & 0.16 & 1.1 & $0.98^{\mathrm{b}}$ \\
\hline PTGS2 & cyclooxygenase-2 & 0.50 & 1.4 & $0.63^{b}$ \\
\hline \multicolumn{5}{|c|}{ GO category: Positive regulation of I-kappaB kinase/NF-kappaB cascade } \\
\hline APOL3 & apolipoprotein L, 3 & 1.24 & 2.4 & $1.2 \times 10^{-8}$ \\
\hline IKBKE & $\begin{array}{l}\text { inhibitor of kappa light polypeptide gene enhancer in B- } \\
\text { cells, kinase epsilon }\end{array}$ & 0.63 & 1.5 & $5.1 \times 10^{-4}$ \\
\hline IKBKE & $\begin{array}{l}\text { inhibitor of kappa light polypeptide gene enhancer in B- } \\
\text { cells, kinase epsilon }\end{array}$ & 0.50 & 1.4 & $3.9 \times 10^{-4}$ \\
\hline FLNA & filamin A, alpha (actin binding protein 280 ) & -0.23 & -1.2 & 0.03 \\
\hline NUP62 & nucleoporin $62 \mathrm{kDa}$ & 0.35 & 1.3 & $1.0 \times 10^{-5}$ \\
\hline NUP62 & nucleoporin $62 \mathrm{kDa}$ & 0.37 & 1.3 & $9.5 \times 10^{-3}$ \\
\hline TICAM2 & toll-like receptor adaptor molecule 2 & 0.36 & 1.3 & $1.6 \times 10^{-3}$ \\
\hline CD40 & CD40 molecule, TNF receptor superfamily member 5 & 0.40 & 1.3 & $3.6 \times 10^{-3}$ \\
\hline TLR3 & toll-like receptor 3 & 0.40 & 1.3 & 0.01 \\
\hline TFG & TRK-fused gene & 0.27 & 1.2 & 0.04 \\
\hline $\mathrm{F} 2 \mathrm{R}$ & coagulation factor II (thrombin) receptor & -0.22 & -1.2 & 0.05 \\
\hline RIPK2 & receptor-interacting serine-threonine kinase 2 & 1.14 & 2.2 & $1.7 \times 10^{-6}$ \\
\hline TNFRSF10B & $\begin{array}{l}\text { tumor necrosis factor receptor superfamily, member } \\
10 \mathrm{~b}\end{array}$ & 0.35 & 1.3 & $1.5 \times 10^{-3}$ \\
\hline TNF & tumor necrosis factor (TNF superfamily, member 2) & -0.46 & -1.4 & $2.1 \times 10^{-3}$ \\
\hline SLC20A1 & $\begin{array}{l}\text { solute carrier family } 20 \text { (phosphate transporter), } \\
\text { member } 1\end{array}$ & -1.17 & -2.3 & $1.4 \times 10^{-3}$ \\
\hline TRIM38 & tripartite motif-containing 38 & 0.33 & 1.3 & 0.04 \\
\hline $\mathrm{BIRC2}$ & baculoviral IAP repeat-containing 2 & 0.62 & 1.5 & $4.8 \times 10^{-3}$ \\
\hline GJA1 & gap junction protein, alpha 1, $43 \mathrm{kDa}$ & -0.64 & -1.6 & 0.02 \\
\hline RELA & $\begin{array}{l}\text { v-rel reticuloendotheliosis viral oncogene homolog A, } \\
\text { nuclear factor of kappa light polypeptide gene enhancer } \\
\text { in B-cells 3, p65 (avian) }\end{array}$ & 0.47 & 1.4 & $1.6 \times 10^{-4}$ \\
\hline \multicolumn{5}{|c|}{ GO category: Positive regulation of JNK cascade } \\
\hline EDA2R & ectodysplasin $\mathrm{A} 2$ receptor & -0.34 & -1.3 & $1.3 \times 10^{-3}$ \\
\hline TLR3 & toll-like receptor 3 & 0.40 & 1.3 & 0.01 \\
\hline TAOK3 & TAO kinase 3 & -0.35 & -1.3 & 0.01 \\
\hline TAOK3 & TAO kinase 3 & -0.28 & -1.2 & $9.0 \times 10^{-3}$ \\
\hline HIPK2 & homeodomain interacting protein kinase 2 & 0.40 & 1.3 & $3.4 \times 10^{-5}$ \\
\hline TNF & tumor necrosis factor (TNF superfamily, member 2) & -0.46 & -1.4 & $2.1 \times 10^{-3}$ \\
\hline
\end{tabular}

$\mathrm{PGE}_{2}$-synthesizing enzymes and differentially expressed genes in selected significant GO categories when comparing $1 \mathrm{~h}$ and $3 \mathrm{~h}$ of TNFa treatment. aPositive M-values indicate genes up-regulated by TNFa, and negative M-values indicate genes down-regulated by TNFa between the $1 \mathrm{~h}$ and $3 \mathrm{~h}$ time points. ${ }^{b}$ Not differentially expressed in the comparison between time-points $1 \mathrm{~h}$ and $3 \mathrm{~h}$. Differential expression is defined as $p<0.05$. 
also decreased the production of $\mathrm{PGE}_{2}$, both in TNF $\alpha$ stimulated cells and in control cells in $24 \mathrm{~h}$ cultures, as shown in Figure 6D.

\section{Involvement of NF-KB in mPGES-1 and COX-2 regulation}

In order to evaluate the role of NF- $\mathrm{kB}$ in the regulation of mPGES-1 and COX-2 expression, the NF- $\mathrm{kB}$ pathway inhibitor Bay 11-7082 (Bay) [48] was used in the experiments. Treatment of the cells with Bay $(2 \mu \mathrm{M})$, decreased the TNF $\alpha$-stimulated expression of mPGES-1 and COX2 , the latter to a higher extent, in $24 \mathrm{~h}$ cultures, as demonstrated by flow cytometric analysis (Figure 7A). In addition, Bay also slightly decreased mPGES-1 expression in control cells (Figure 7A). To confirm the inhibition of NF$\kappa B$ by Bay, the amount of phosphorylated NF- $\mathrm{kB}$ p65 (p$\mathrm{NF} \kappa \mathrm{B}$ ) in fibroblasts stimulated with $\mathrm{TNF} \alpha$ for $1,3,6$ and $24 \mathrm{~h}$ was analyzed using p-NFKB-specific antibodies (Figure $7 \mathrm{~B})$. The results, expressed as relative to control cells at the $1 \mathrm{~h}$ time point, showed a peak of p-NF-kB at $1 \mathrm{~h}$ of incubation with TNF $\alpha$ (Figure 7B). Treatment of the cells with Bay $(2 \mu \mathrm{M})$ in combination with TNFo significantly decreased $\mathrm{p}-\mathrm{NF}-\mathrm{kB}$ in $1 \mathrm{~h}$ cultures, as demonstrated in Figure 7B. The effect of Bay on p-NF- $\mathrm{kB}$ was also studied at an earlier time point, 10 minutes after stimulation (Figure $7 \mathrm{C}$ ). The results, expressed as $\mathrm{p}-\mathrm{NF}-\mathrm{kB}$ relative to control cells at the start of incubation, showed that at the 10 minute time point, the TNF $\alpha$-stimulated level of pNF- $\kappa B$ was significantly decreased in the presence of Bay $(2.0 \mu \mathrm{M}$, Figure $7 \mathrm{C})$. Furthermore, Bay $(1-4 \mu \mathrm{M})$ reduced the basal production of $\mathrm{PGE}_{2}$, compared to control cells in $24 \mathrm{~h}$ cultures (Figure 7D). Treatment of TNF $\alpha$-stimulated cells with Bay (1-4 $\mu \mathrm{M})$ had no effect on $\mathrm{PGE}_{2}$ production in $24 \mathrm{~h}$ cultures (Figure 7D), but the inhibitor (2 $\mu \mathrm{M})$ decreased the TNF $\alpha$-stimulated $\mathrm{PGE}_{2}$ production in $6 \mathrm{~h}$ cultures (Figure 7E). To further confirm the involvement of NF- $\mathrm{kB}$ in the regulation of mPGES-1, COX-2 and $\mathrm{PGE}_{2}$, an additional inhibitor of NF-kB, Ro 106-9920 (Ro) [49], was used. Treatment of the cells with Ro $(4 \mu \mathrm{M})$, decreased the TNF $\alpha$-stimulated expression of mPGES-1 and COX-2 in $24 \mathrm{~h}$ cultures, as demonstrated by flow cytometric analysis (Figure 8A). Concurrent with the protein expression results, the inhibitor $(4 \mu \mathrm{M})$ also decreased the production of $\mathrm{PGE}_{2}$ in $\mathrm{TNF} \alpha$-stimulated cells in $24 \mathrm{~h}$ cultures, as shown in Figure 8B.

\section{Discussion}

$\mathrm{PGE}_{2}$ is involved in numerous inflammatory associated diseases including the chronic inflammatory disease periodontitis. The aim of this study was to investigate the global gene expression profile of TNF $\alpha$-stimulated human gingival fibroblasts with a focus on signal transduction pathways related to the expression of mPGES-1 and COX-2. We used a time-course factorial design for the oligonucleotide microarray hybridizations, which enabled us to statistically discern the interaction effect between the TNF $\alpha$ treatment and time aspect in the experiments studied. To our knowledge, this is the first study investigating the global gene expression profile of TNF $\alpha$-stimulated gingival cells as an in vitro model of gingival inflammation. In the current study, we demonstrate a TNF $\alpha$-stimulated up-regulation of mPGES-1 and COX-2 expression, both at mRNA and protein levels, accompanied by enhanced $\mathrm{PGE}_{2}$ production. In addition, our microarray results showed a regulation of immune response, apoptosis and signal transduction gene categories in response to TNF $\alpha$ treatment of gingival fibroblasts, including positive regulation of the signal pathways JNK and NF-KB.

The TNF $\alpha$ up-regulated mPGES-1 and COX-2 expression, accompanied by increased $\mathrm{PGE}_{2}$ production, is in line with our previously published results on gingival fibroblasts [30]. In contrast to the mPGES-1 and COX-2 enzymes, the expression of the PGE synthases mPGES-2 and cPGES was not affected by TNFo treatment, highlighting the importance of mPGES- 1 and COX-2 in the regulation of inflammatory-induced $\mathrm{PGE}_{2}$ production. However, when considering the similar kinetics of $\mathrm{PGE}_{2}$ production and COX-2 expression, as well as the magnitude of COX-2 induction compared to mPGES-1, COX-2 seems to be the more important enzyme driving the $\mathrm{TNF} \alpha$ induced $\mathrm{PGE}_{2}$ production in gingival fibroblasts. Increased $\mathrm{PGE}_{2}$ production, via induction of the $\mathrm{PGE}_{2}-$ synthesizing enzymes mPGES-1 or COX-2, has also been reported in other cell types stimulated with TNFo, including synovial cells, chondrocytes and colonocytes $[38,50,51]$.

Various intracellular signaling pathways have been reported to be involved in inflammatory-induced $\mathrm{PGE}_{2}$ synthesis, mainly through regulation of $\mathrm{COX}-2$, which is the most widely studied enzyme of the $\mathrm{PGE}_{2}$ synthesis chain. In contrast, limited reports exist regarding the regulation of the PGE synthases downstream of COX-2. To further explore the regulation of mPGES-1 and related $\mathrm{PGE}_{2}$-synthesizing enzymes in gingival fibroblasts, we here used a global gene expression profiling approach to achieve a broader view of the genes and signal pathways related to the regulation of mPGES-1, in parallel with $\mathrm{COX}-2$, using microarray analysis of TNF $\alpha$-treated gingival fibroblasts. The effect of TNF $\alpha$ on global gene expression profiles has previously been investigated in synovial fibroblasts, preosteoblasts and HeLa cells, but not in gingival cells [52-56]. With regard to periodontal disease, microarray analysis of gingival tissue has been used in an attempt to define subclasses of periodontitis and to evaluate the effect of periodontal therapy $[57,58]$. In addition, blood cell gene expression profiling has been performed 
Table 2: Differential expression of PGE $_{2}$-synthesizing enzymes when comparing $1 \mathrm{~h}$ and $6 \mathrm{~h}$ of TNFa treatment.

\begin{tabular}{llccc}
\hline Symbol & Gene Name & M-valuea & Fold Change & p value \\
& & & \\
\hline PTGES & microsomal prostaglandin E synthase-1 (probe 1) & 0.87 & 1.8 & $6.2 \times 10^{-7}$ \\
PTGES & microsomal prostaglandin E synthase-1 (probe 2) & 0.54 & 1.5 & $1.8 \times 10^{-3}$ \\
PTGES2 & microsomal prostaglandin E synthase-2 & -0.06 & 1.0 & $0.83^{\mathrm{b}}$ \\
PTGES3 & cytosolic prostaglandin E synthase (probe 1) & 0.03 & 1.0 & $0.78^{\mathrm{b}}$ \\
PTGES3 & cytosolic prostaglandin E synthase (probe 2) & 0.03 & 1.0 & $0.98^{\mathrm{b}}$ \\
PTGS2 & cyclooxygenase-2 & 0.85 & 1.8 & 0.03 \\
\hline
\end{tabular}

aPositive M-values indicate up-regulated genes, and negative $\mathrm{M}$-values indicate down-regulated genes. ${ }^{b}$ Not differentially expressed in the comparison between time-points $1 \mathrm{~h}$ and $6 \mathrm{~h}$. Differential expression is defined as $p<0.05$.

in subjects with aggressive periodontitis [59]. Concerning gingival fibroblasts, microarray studies have been performed on unstimulated cells from healthy and inflamed gingival tissue, and on IL-1 $\beta$-stimulated immortalized cells $[60,61]$. However, a majority of the abovementioned microarray studies on cell cultures use only one time point of RNA analysis after stimulation. In this work, using primary gingival fibroblasts, we employed a timecourse factorial design to extract as much relevant information as possible from our data set. Commonly, when using a simpler design for a time series experiment, it becomes difficult to relate the gene expression differences at the different time points to each other. This is greatly facilitated by the use of a time-course factorial design, which allows for the identification of the genes that are differentially regulated between the time points due to TNF $\alpha$ treatment [45].

Our results from the microarray analysis indicated the JNK and NF- $\mathrm{KB}$ pathways as possible targets for interrupting the TNF $\alpha$-induced signal transduction leading to increased expression of the $\mathrm{PGE}_{2}$-synthesizing enzymes mPGES-1 and COX-2. Thus, we next further investigated the involvement of JNK and NF- $\mathrm{KB}$ in the TNF $\alpha$-stimulated mPGES-1 and COX-2 expression. By using inhibitors specific for these signal pathways, we could demonstrate that JNK and NF- $\mathrm{kB}$ are partly involved in the complex network of intracellular signal transduction pathways leading to increased expression of mPGES-1 and COX-2, as well as $\mathrm{PGE}_{2}$ production, in response to the inflammatory cytokine TNF $\alpha$. To our knowledge, this is the first study pointing out the involvement of JNK in up-regulation of mPGES-1 expression in TNF $\alpha$-stimulated cells. However, previous studies have shown that mPGES- 1 is stimulated by IL- $1 \beta$ through the JNK pathway in cardiac myocytes, cardiac fibroblasts and A549 human lung epithelial cells $[36,62,63]$. In this study we also show that JNK is involved in TNF $\alpha$-induced COX-2 expression in gingival fibroblasts, suggesting that JNKdependent decrease of mPGES-1 may not be the major event whereby the inhibition of this signal pathway exerts its effect on $\mathrm{PGE}_{2}$ production. The finding that $\mathrm{COX}-2$ expression was somewhat more influenced by inhibition of the JNK pathway, suggests that the JNK pathway may be more significant for COX-2 induction by TNFa in gingival fibroblasts. The involvement of JNK in TNF $\alpha$ induced COX-2 expression is in line with results obtained from human alveolar epithelial cells and murine osteoblasts $[64,65]$. Similarly, IL-1 $\beta$ - and lipopolysaccharideinduced COX-2 has been shown to be mediated through JNK in other cell types $[66,67]$. In contrast, it has also been reported that COX-2 expression induced by epidermal growth factor is unaffected by JNK inhibition in astrocytes, emphasizing the differences between cell types as well as the inflammatory stimuli used for investigation of signal transduction pathways [68].

The JNK pathway has been implicated in chronic inflammatory disorders such as rheumatoid arthritis and inflammatory bowel disease [69,70]. Moreover, JNK-1 deficiency as well as chemical JNK inhibition has been demonstrated to prevent joint destruction in rodent models of rheumatoid arthritis [69,71,72]. Thus, our novel finding that JNK is partly involved in the regulation of TNF $\alpha$-induced mPGES-1 expression, which in concert with COX-2 regulates $\mathrm{PGE}_{2}$ production in gingival fibroblasts, indicates that this signal pathway may also be of importance in the pathogenesis of periodontitis.

In addition to the JNK pathway, we also found that the NF- $\mathrm{KB}$ pathway was involved in the regulation of mPGES- 1 and COX-2 in gingival fibroblasts stimulated with TNF $\alpha$. Our results pointing out the NF-kB pathway in the regulation of mPGES-1 are in line with our previous observations [19]. Induction of mPGES-1 expression using another inflammatory mediator, IL-1 $\beta$, has been reported to be mediated by NF- $\mathrm{kB}$ in A549 cells [73]. In regard to COX-2 regulation, the involvement of the NF$\kappa B$ pathway in the signal transduction of TNF $\alpha$-induced COX-2 expression has been observed in other cell types, including endothelial cells and astrocytes [74,75]. Con- 


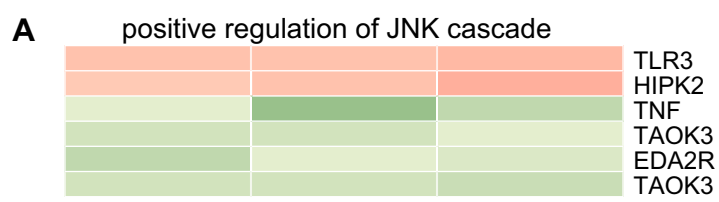

B positive regulation of I-kappaB kinase/NF-kappaB cascade

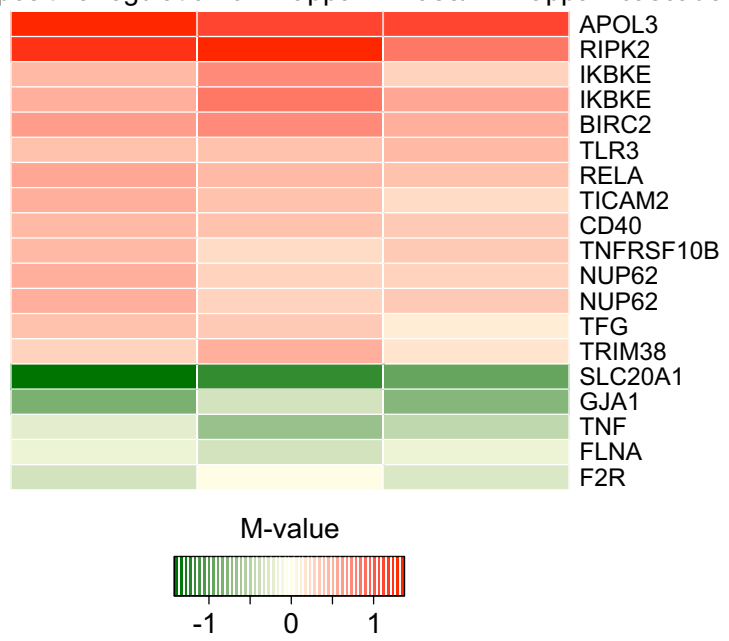

Figure 5 Heat map. A heat map demonstrating the relative level of differentially expressed genes between the time points $1 \mathrm{~h}$ and $3 \mathrm{~h}$. The color of each gene relates to its $\mathrm{M}$-value ( $\log _{2}$ ratio of (gene expression of TNFa treated cells/gene expression of control cells)). A positive M-value corresponds to a higher expression in the TNFa treated cells. Gene symbols [91] are used for gene identification. The three columns represent the three cell lines used in the study. (A) Heat map for the GO-term GO:0046330 (positive regulation of JNK cascade). (B) Heat map for the GO-term GO:0043123 (positive regulation of I-kappaB kinase/NF-kappaB cascade).

cerning $\mathrm{PGE}_{2}$ production, no decrease was observed in TNF $\alpha$-stimulated $\mathrm{PGE}_{2}$ production in $24 \mathrm{~h}$ cultures, in contrast to the inhibition observed in $6 \mathrm{~h}$ cultures. One reason for the lack of inhibition of $\mathrm{PGE}_{2}$ in $24 \mathrm{~h}$ cultures by the NF-kB inhibitor Bay, in contrast to mPGES- 1 and COX-2 expression, may be a toxic effect of the inhibitor, affecting the release of $\mathrm{PGE}_{2}$ although no visual signs of cellular toxicity were observed. However, when using the NF- $\kappa B$ inhibitor Ro, reported to inhibit NF- $\mathrm{KB}$ via selective inhibition of TNF $\alpha$-induced I $\mathrm{B} \alpha \alpha$ [49], it decreased the TNF $\alpha$-stimulated expression of mPGES-1 and COX-2 as well as the production of $\mathrm{PGE}_{2}$ in $24 \mathrm{~h}$ cultures. Furthermore, both the NF- $\mathrm{kB}$ inhibitors Bay and Ro as well as the JNK inhibitor SP decreased the basal expression of mPGES-1 in cells not treated with TNF $\alpha$, which might be due to slightly raised basal levels of mPGES-1 expression resulting from a lingering effect of the serum present in growth medium before the start of cell culture experiments.
A time-course factorial microarray analysis, like the one performed in this work, yields massive amounts of data. In this study we have focused on the signal transduction aspect, especially the JNK and NF-kB pathways, in order to investigate the regulation of mPGES-1 and $\mathrm{COX}-2$ expression in relation to $\mathrm{PGE}_{2}$ production. Inhibition of JNK and NF-kB signal pathways by SP and Ro abolished the production of $\mathrm{PGE}_{2}$, although the induction of mPGES- 1 and COX-2 by TNF $\alpha$ was not completely abrogated. One explanation for this might be that other enzymes may contribute to the production of $\mathrm{PGE}_{2}$ stimulated by TNF $\alpha$. For instance, it is known that the signal pathways JNK and NF- $\mathrm{kB}$, in addition to the COX-2 and mPGES-1 enzymes, are also involved in the regulation of $\mathrm{CPLA}_{2}$, an upstream key enzyme of the $\mathrm{PGE}_{2}$ synthesis reported to be induced by TNF $\alpha$ in gingival fibroblasts [76-78]. Another explanation for the strong inhibition of $\mathrm{PGE}_{2}$ production, in contrast to the partial reduction of mPGES-1 and COX-2 expression, may be a synergistic effect of the concerted inhibition of these two enzymes, since they are functionally coupled and responsible for the coordinated $\mathrm{PGE}_{2}$ synthesis [79]. In addition, one has to be aware that the JNK and NF- $\mathrm{kB}$ pathways activated by TNF $\alpha$ may not be entirely responsible for the increased expression of mPGES- 1 and COX-2. There are many additional TNF $\alpha$-regulated genes and pathways involved in the regulation of inflammatory conditions, including $\mathrm{PGE}_{2}$ regulatory enzymes, that merit further study, and investigations are ongoing to continue charting the genome-wide effect of TNF $\alpha$ on gingival fibroblasts.

\section{Conclusions}

We here present for the first time a gene expression profiling approach to explore the signal pathways involved in the TNF $\alpha$-stimulated $\mathrm{PGE}_{2}$ production and $\mathrm{mPGES}-1$ and COX-2 expression in gingival fibroblasts. In the global gene expression profile, the enrichment analysis of microarray data identified the two signal transduction pathways JNK and NF- $\mathrm{KB}$ as positively regulated by the inflammatory cytokine TNF $\alpha$. Inhibitors of the JNK and NF- $\mathrm{B}$ p pathways reduced the TNF $\alpha$-stimulated expression of mPGES-1 and to a higher extent COX-2, accompanied by abolished $\mathrm{PGE}_{2}$ production. Altogether, the microarray and phosphorylation data provide insight into the regulatory network of signal pathways related to PGE synthase, $\mathrm{COX}-2$ and $\mathrm{PGE}_{2}$ production in gingival fibroblasts. The involvement of JNK and NF- $\mathrm{KB}$ in the regulation of $\mathrm{PGE}_{2}$ production induced by $\mathrm{TNF} \alpha$ in gingival fibroblasts suggests these two signal pathways as key elements in the inflammatory-induced $\mathrm{PGE}_{2}$ production in gingiva, and also as possible attractive targets in the chronic inflammatory disease periodontitis. 
A

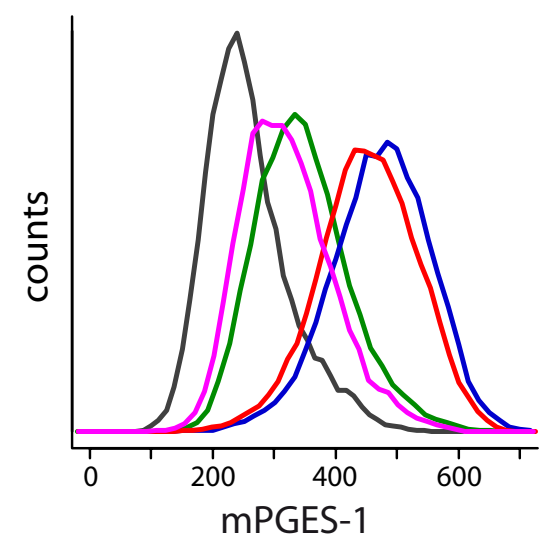

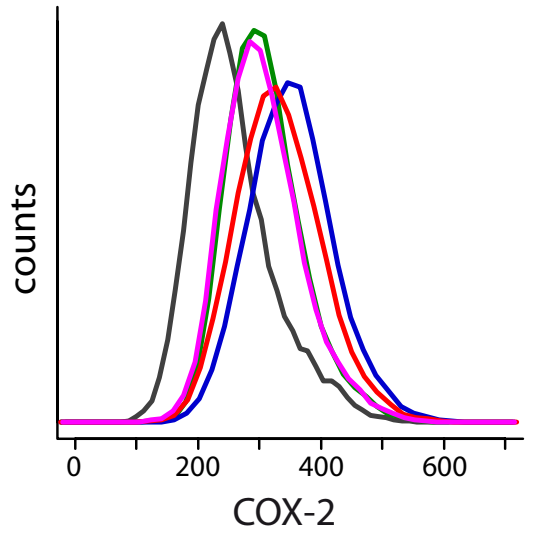

TNF $\alpha$

$\mathrm{TNF} \alpha+\mathrm{SP}$
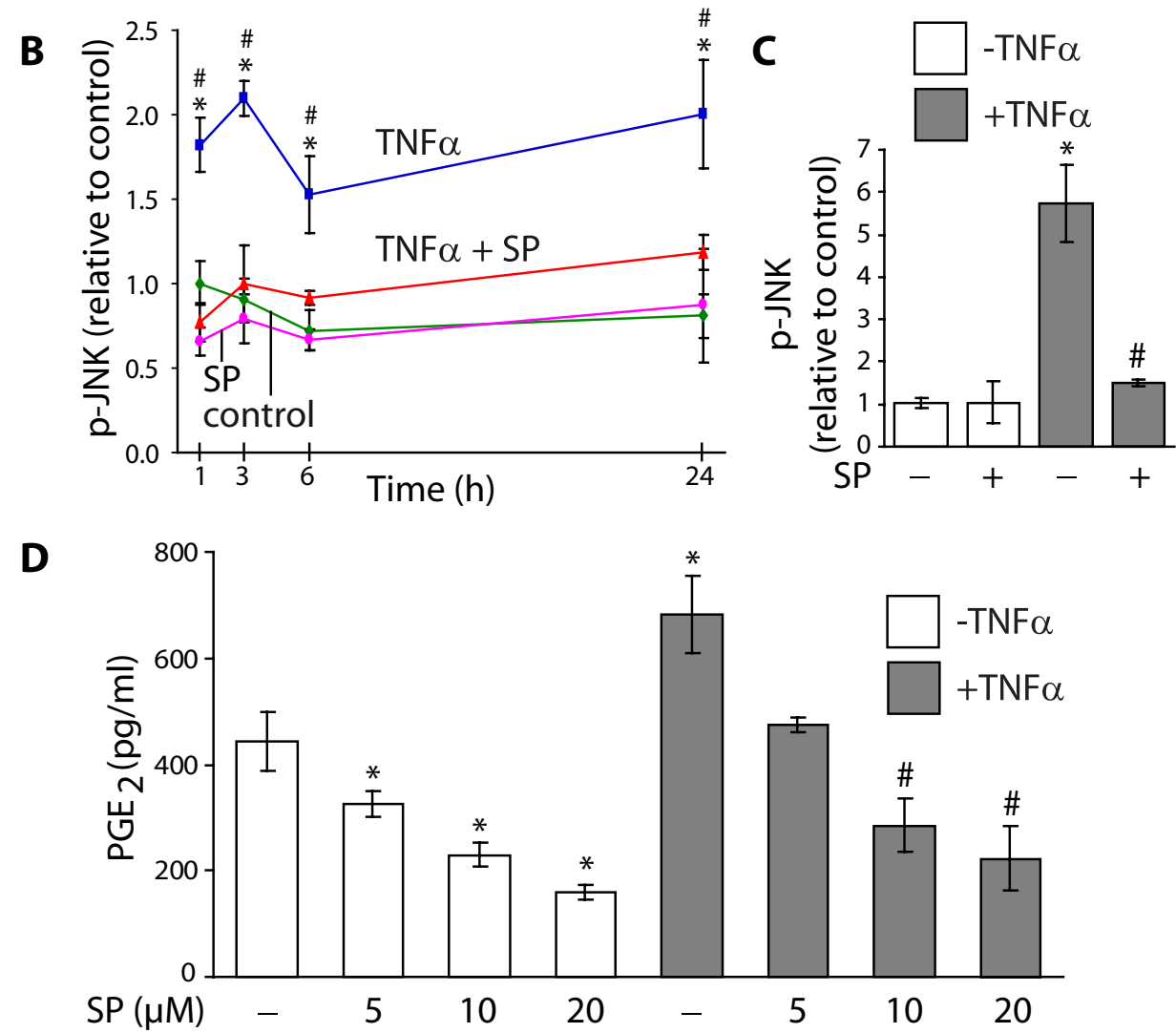

Figure 6 Involvement of C-Jun N-terminal kinase (JNK) in the regulation of mPGES-1 and COX-2. (A) Gingival fibroblasts were treated with TNFa $(20 \mathrm{ng} / \mathrm{ml})$ with or without the JNK inhibitor SP600125 (SP, 10 MM) for $24 \mathrm{~h}$. Expression of mPGES-1 and COX-2 was measured by flow cytometry using specific antibodies. (B-C) Gingival fibroblasts were treated with TNFa $(20 \mathrm{ng} / \mathrm{ml}$ ) with or without SP (10 $\mu \mathrm{M})$ for 1, 3, 6 and $24 \mathrm{~h}$ (B) or $10 \mathrm{minutes}$ (C). Cells were lysed and total protein was analyzed for phosphorylated JNK ( $p$-JNK) and expressed as relative to control cells at $1 \mathrm{~h}$ (B) or at start of incubation (C). Data is presented as mean \pm s.d. Asterisks $\left.{ }^{*}\right)$ indicate a significant difference $(p<0.05)$ between TNFa-stimulated cells and control cells at each time point, and hash symbols $(\#)$ indicate a significant difference $(p<0.05)$ between TNFa-stimulated cells and cells treated with TNFa in combination with SP at each time point. (D) Gingival fibroblasts were cultured with the indicated doses of SP in the absence or presence of TNFa (20 ng/ $\mathrm{ml}$ ) for $24 \mathrm{~h}$. Levels of $\mathrm{PGE}_{2}$ in the culture media were measured by EIA using Luminex technology. Data is presented as mean \pm s.d. Asterisks $\left({ }^{*}\right)$ indicate a significant difference compared to control cells not treated with TNFa or SP, and hash symbols (\#) indicate a significant difference compared to cells treated with TNFa only $(p<0.05)$. The results are representative for all three cell lines and all analyses were performed in triplicates. 
A

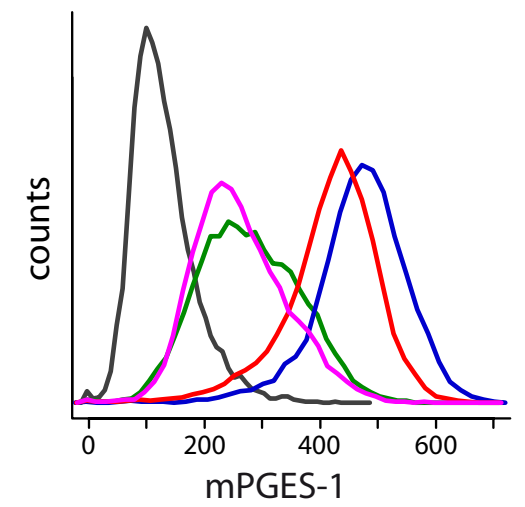

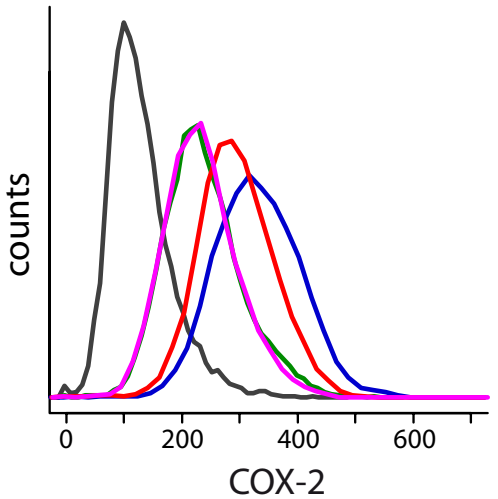

TNF $\alpha$

TNF $\alpha+$ Bay
B

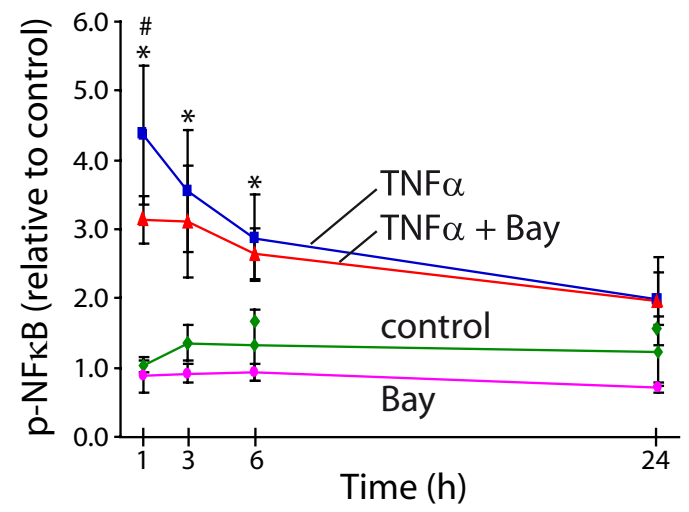

D

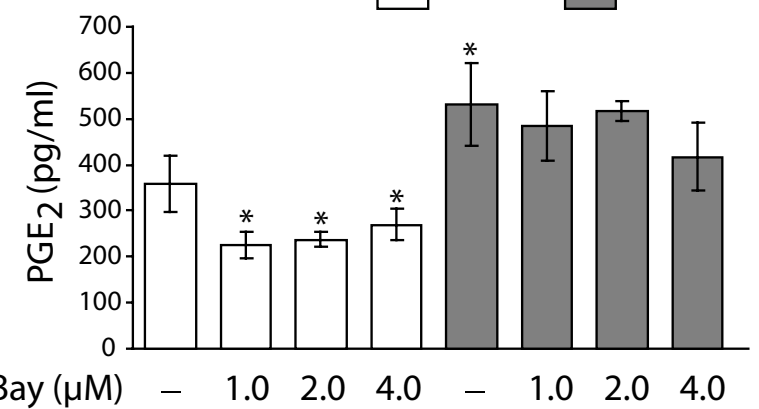

C

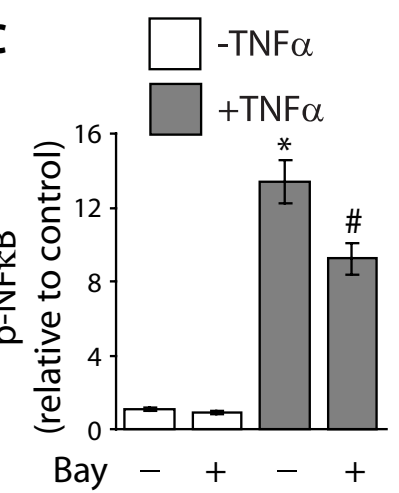

E

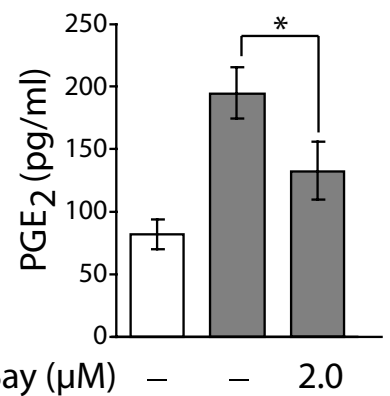

Figure 7 Involvement of Nuclear Factor-kappaB (NF-KB) in mPGES-1 and COX-2 regulation. (A) Gingival fibroblasts were treated with TNFa (20 $\mathrm{ng} / \mathrm{ml}$ ) with or without the NF-KB pathway inhibitor Bay 11-7082 (Bay, $2.0 \mu \mathrm{M}$ ) for $24 \mathrm{~h}$. Expression of mPGES-1 and COX-2 was measured by flow cytometry using specific antibodies. (B-C) Gingival fibroblasts were treated with TNFa (20 ng/ml) with or without Bay $(2.0 \mu \mathrm{M})$ for 1, 3, 6 and $24 \mathrm{~h}$ (B) or 10 minutes (C). Cells were lysed and total protein was analyzed for phosphorylated NF-kB p65 ( $\mathrm{p}-\mathrm{NF}-\mathrm{kB}$ ) and expressed as relative to control cells at $1 \mathrm{~h}$ (B) or at start of incubation (C). Data is presented as mean \pm s.d. Asterisks $\left(^{*}\right)$ indicate a significant difference $(p<0.05)$ between TNFa-stimulated cells and control cells at each time point, and the hash symbols (\#) indicate a significant difference $(p<0.05)$ between TNFa-stimulated cells and cells treated with TNFa together with Bay at each time point. (D) Gingival fibroblast were cultured with the indicated doses of Bay in the absence or presence of TNFa $(20 \mathrm{ng} / \mathrm{ml})$ for $24 \mathrm{~h}$. Levels of $\mathrm{PGE}_{2}$ in the culture media were measured by ElA on a Luminex system, and data is presented as mean \pm s.d. Asterisks $\left(^{*}\right)$ indicate a significant difference from control cells not treated with TNFa or Bay $(p<0.05)$. (E) Gingival fibroblast were cultured with Bay $(2 \mu \mathrm{M})$ in the absence or presence of TNFa $(20 \mathrm{ng} / \mathrm{ml})$ for $6 \mathrm{~h}$. Levels of $\mathrm{PGE}_{2}$ in the culture media were measured by ElA, and data is presented as mean \pm s.d. Asterisk $\left(^{*}\right)$ indicates a significant difference $(p<0.05)$. The results are representative for all three cell lines and all analyses were performed in triplicates. 


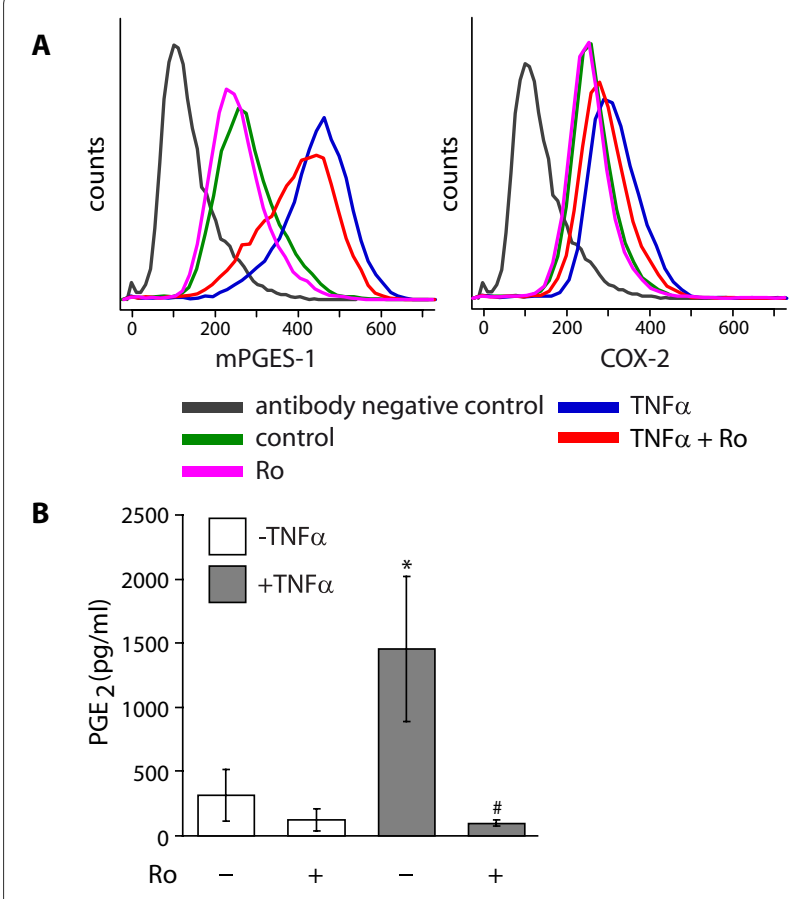

Figure 8 Inhibition of Nuclear Factor-kappaB (NF-kB) by Ro 1069920 decreases MPGES-1 and COX-2 expression. (A) Gingival fibroblasts were treated with TNFa $(20 \mathrm{ng} / \mathrm{ml})$ with or without the NF-KB activation inhibitor Ro 106-9920 (Ro, $4.0 \mu \mathrm{M})$ for $24 \mathrm{~h}$. Expression of mPGES- 1 and COX-2 was measured by flow cytometry using specific antibodies. (B) Gingival fibroblast were cultured with Ro $(4.0 \mu \mathrm{M})$ in the absence or presence of TNFa $(20 \mathrm{ng} / \mathrm{ml})$ for $24 \mathrm{~h}$. Levels of PGE 2 in the culture media were measured by EIA, and data is presented as mean \pm s.d. Asterisk $\left(^{*}\right)$ indicates a significant difference compared to control cells not treated with TNFa or Ro, and the hash symbol (\#) indicates a significant difference compared to cells treated with TNFa only $(p<$ 0.05). The results are representative for all three cell lines and all analyses were performed in triplicates.

\section{Methods}

\section{Cell culture of human gingival fibroblasts}

Human gingival fibroblasts were established from gingival biopsies obtained from 3 patients, 3 to 12 years of age, with no clinical signs of periodontal disease. The protocol, including the collection of gingival biopsies, was approved by the Regional Ethics Board in Stockholm (Dnr 377/98 and 2007/114-31/4). Minced pieces of gingival tissue were explanted to $25 \mathrm{~cm}^{2}$ Falcon tissue culture flasks containing $5 \mathrm{ml}$ of Dulbecco's Modified Eagle Medium (DMEM) supplemented with 50 units $/ \mathrm{ml}$ penicillin, $50 \mu \mathrm{g} / \mathrm{ml}$ streptomycin $(50 \mu \mathrm{g} / \mathrm{ml})$ and $5 \%$ fetal calf serum (FCS, Invitrogen Life Technologies, Scotland, UK). Gingival fibroblasts were obtained by trypsinization of the primary outgrowth of cells. The cells were grown at $37^{\circ} \mathrm{C}$ with $5 \% \mathrm{CO}_{2}$ and routinely passaged using $0.025 \%$ trypsin in phosphate-buffered saline (PBS) containing $0.02 \%$ EDTA. The fibroblasts used in the experiments proliferated in the logarithmic phase between the 9th and 14th passage. Gingival fibroblasts were seeded in Petri dishes in DMEM supplemented with 5\% FCS and cultured for $24 \mathrm{~h}$ at $37^{\circ} \mathrm{C}$. The cell layers were then rinsed with serum-free DMEM followed by the addition of DMEM with or without the inflammatory mediator TNF $\alpha$ (20 ng/ml, according to previous dose-response studies $[19,30])$ and in the absence or presence of the inhibitors SP600125 (SP; Sigma-Aldrich, St. Louis, MO, USA), Bay 11-7082 (Bay, Sigma-Aldrich) or Ro 106-9920 (Ro, Tocris Bioscience, Bristol, UK). After different incubation periods, as indicated in the figure legends, culture medium was removed and stored at $-20^{\circ} \mathrm{C}$ for subsequent $\mathrm{PGE}_{2}$ determination. The cell monolayer was washed twice with ice-cold PBS and the cells were used for oligonucleotide microarray, flow cytometry or phosphorylation specific luminex analyses.

\section{RNA extraction}

Gingival fibroblasts were seeded and grown as described above. For each of the three cell lines, two 100-mm Petri dishes were used for each treatment. After incubation for 1,3 or $6 \mathrm{~h}$ with or without TNF $\alpha(20 \mathrm{ng} / \mathrm{ml})$, the cells were immediately frozen in liquid nitrogen and then stored at $-70^{\circ} \mathrm{C}$ for subsequent isolation of total RNA. Total RNA was isolated from fibroblasts using the commercially available RNeasy kit (Qiagen Inc., CA, USA) and quantified spectrophotometrically at 260/280 nm. The RNA from each pair of dishes with identical cell line and treatment were pooled and treated as one sample throughout further analyses. The RNA quality was assessed using the RNA 6000 Nano LabChip kit of the Bioanalyzer system (Agilent Technologies, Palo Alto, CA, USA).

\section{Labeling and CDNA synthesis for microarray analysis}

The synthesis and labeling of cDNA was performed as previously described by Lindberg et al. 2006[80] Briefly, cDNA was synthesized using random hexamer primers (Operon, Alameda CA, USA) and Superscript III (Invitrogen, San Diego CA, USA). The reaction was terminated and the RNA was hydrolyzed with EDTA and $\mathrm{HCl}$. $\mathrm{NaOH}$ was then used to restore $\mathrm{pH}$ before proceeding with cDNA purification using MinElute Reaction Cleanup Kit (Qiagen, Hilden, Germany). For washing and elution of the cDNA, 80\% EtOH and $\mathrm{NaHCO}_{3} \mathrm{pH} 9$ was used instead of supplied buffers due to the presence of TRIS, which would affect the labeling reaction. Labeling was performed using $\mathrm{Cy} 3$ and $\mathrm{Cy} 5$ mono-reactive esters from Amersham-Biosciences (Little Chalfont, Bucks, UK). The labeling mixture was then purified using MinElute Reaction Cleanup Kit (Qiagen) according to the manufacturer's protocol. A Nanodrop instrument (Nanodrop Technologies, Wilmington, DE USA) was used to confirm labeling success and to measure fluorophore concentra- 
tions. The fluorophore concentrations of the labeling reactions were used to balance the sample volumes. To obtain equal fluorophore amounts within each hybridization, a smaller volume of the sample with a higher fluorophore concentration was hybridized with the entire volume of the sample with a lower fluorophore concentration.

\section{Oligonucleotide microarray}

The oligonucleotide microarrays used in this study were printed at the KTH microarray core facility [81]. The 70mer oligos originate from version 3.03 of Operons Human Genome Oligo Set, and the microarray contains 35344 features representing 28948 Entrez Gene ID:s [82] of which 17972 are unique. Additional information regarding the oligonucleotide microarray can be found in additional files 10 and 11 .

\section{Hybridization}

Hybridization was performed as previously described [80]. Briefly, the microarrays were put in a trough and prehybridized with a bovine serum albumin based buffer for 30 minutes in a $42^{\circ} \mathrm{C}$ water bath. After washing the microarrays, the corresponding Cy3 and $\mathrm{Cy} 5$ labeled samples were pooled and hybridization buffer was added to the mixture. Lifter slips (Erie Scientific Company, Shelton, CT, USA) were used to contain the hybridization mixture on the array during hybridization. The arrays were then hybridized over night in a $42^{\circ} \mathrm{C}$ water bath. After subsequent washing the arrays were immediately scanned.

\section{Scanning and image processing}

Scanning was performed on an Agilent G2565BA scanner (Agilent Technologies, Palo Alto, CA, USA) using a scanner resolution of $10 \mu \mathrm{m}$, as previously described [80]. The software GenePix 5.1.0.0 (Axon Instruments, Foster City, CA, USA) was used to extract the raw signals from the TIFF images and to assign each spot an ID.

\section{Statistical methods and low level analysis of microarray data}

The data was analyzed using different packages in the software R [83]. All packages except the KTH package [81] are available in the Bioconductor open source software project for analysis of genomic data [84]. First, the raw data from GenePix was read into R. Thereafter, four filters were used to remove spots with abnormal physical properties, as previously described [80]. On average, 75\% of all spots passed the filters for each slide. After filtering, the slides were normalized using print tip Lowess normalization [85]. A linear model in the Bioconductor package LIMMA (Linear models for microarray data) was set up to estimate the $\mathrm{M}$-value and variance for each gene. The $\mathrm{M}$-value is the $\log _{2}$ of the fold change (e.g. gene expression of TNF $\alpha$ treated cells/gene expression of control cells). Subsequently, differentially expressed (DE) genes were identified in the different contrasts of interest by using a moderated $\mathrm{t}$-test where information is borrowed across all features present on the microarray to obtain a better variance estimate [86]. A false discovery rate algorithm was then applied to the calculated $\mathrm{p}$ values to correct for multiple testing [87]. Thereafter, differentially expressed genes were defined as genes with a $\mathrm{q}$ value $<0.05$ (the false discovery rate analog of a $p$ value), meaning that the proportion of false positives among the differentially expressed genes was 0.05 . The Gene Ontology database was then used to assign functions to genes [88]. Utilizing the Gene Ontology annotation, enrichment analysis was performed to discover biological themes among the differentially expressed genes in the different comparisons [89]. Basically, a conditional hypergeometric test is performed for each GO-term where each gene is counted only in the most specific statistically significant GO-term to decorrelate and facilitate the interpretation of the results. False discovery rate was also used here to correct for multiple testing.

\section{Design of microarray experiments}

The experimental design of the microarray study was set up as a time-course factorial design, to best observe the $\mathrm{TNF} \alpha$-induced gene expression changes over time [45]. A $\mathrm{C}++$ program (provided by the authors of reference [45] on request) was used to determine the exact layout of the design in order to estimate the interaction effect between treatment and time, i.e. genes that are differentially expressed over time, with optimal statistical efficiency [45]. The experimental design is illustrated in Figure 3A, where each arrow represents one hybridization. Thus, each sample was measured four times in this design, and the design was repeated for each of the three cell lines.

\section{Accession codes}

The microarray data set has been deposited at Gene Expression Omnibus (National Center for Biotechnology Information), accession number GSE13903 [90].

\section{Flow cytometric analysis}

Cells were seeded and grown in $60-\mathrm{mm}$ petri dishes as described above. After $24 \mathrm{~h}$ of treatment, the cells were collected by trypsinization, and washed three times with PBS. Thereafter, the cells were fixed in $2 \%$ paraformaldehyde for $15 \mathrm{~min}$ at room temperature (RT) and washed with PBS prior to permeabilization with SAP buffer containing 0.1\% Saponin (Sigma-Aldrich) in PBS (15 min, $\mathrm{RT}$ ). The cells were then incubated with primary antibodies for mPGES-1 (monoclonal mouse, Cayman) mPGES2 (polyclonal rabbit, Cayman), cPGES (polyclonal rabbit, Cayman) or COX-2 (monoclonal mouse, Cayman) for 40 min in the dark (RT). Antibodies were titrated in prelimi- 
nary experiments. After washing with SAP-buffer, the cells were incubated with a secondary goat anti-mouse Fluorescein Isothiocyanate-labeled antibody (DakoCytomation, Glostrup, Denmark) or sheep anti-rabbit Phycoerythrin-labeled antibody (Serotec, Oxford, UK) in the dark for $40 \mathrm{~min}$ at $4^{\circ} \mathrm{C}$. Thereafter, the cells were washed with SAP-buffer, resuspended in PBS and analyzed in a FACSCalibur $^{\text {mu }}$ flow cytometer using CellQuest software (Becton \& Dickinson, San Jose, CA, USA). For each sample, 10000 events were acquired and cells were analyzed regarding the expression of mPGES-1, mPGES-2, cPGES or COX-2. The results obtained are illustrated as histograms of cell counts, drawn using the program R, together with the software package rflowcyt $[83,84]$.

\section{Western blot analysis}

Cells were seeded and grown in $60-\mathrm{mm}$ petri dishes as described above. To isolate the total protein, the cells were washed, resuspended in PBS and centrifuged. Thereafter, the pellet was resuspended in $100 \mu$ lysis buffer (10 mM HEPES pH 7.9, $10 \mathrm{mM} \mathrm{KCl}, 0.1 \mathrm{mM}$ EDTA, $0.1 \mathrm{mM}$ EGTA, $1 \mathrm{mM}$ DTT and protease inhibitors: 1 $\mathrm{mM}$ PMSF, pepstatin, aprotinin and leupeptin at $1 \mu \mathrm{g} /$ $\mathrm{ml})$. The protein concentration of the cell lysates was determined using the Bradford method (Protein Assay; Bio-Rad Laboratories, Hercules, CA, USA) using bovine serum albumin (Sigma-Aldrich) as standard. Equal amounts of the obtained protein were separated by electrophoresis on a $4-15 \%$ linear gradient polyacrylamide tris- $\mathrm{HCl}$ gel (Bio-Rad) and transferred to a nitrocellulose membrane (Bio-Rad). The membrane was then immersed in blocking buffer (Tris buffered saline with $0.1 \%$ Tween 20, TBST, pH 8.0 with 5\% defatted dry milk; Bio-Rad) for $1 \mathrm{~h}$ at $\mathrm{RT}$ and incubated at $4^{\circ} \mathrm{C}$ over night in blocking buffer with primary antibody diluted 1:200 for mPGES-1 (monoclonal mouse IgG, Cayman), 1:250 for mPGES-2 (polyclonal rabbit IgG, Cayman), 1:150 for cPGES (polyclonal rabbit IgG, Cayman), 1:1000 for COX-2 (monoclonal mouse IgG, Cayman) and 1:20000 for the loading control actin (polyclonal rabbit IgG, Sigma-Aldrich). Following primary antibody incubation, the membranes were washed in TBST and incubated for $1 \mathrm{~h}$ in RT with horseradish peroxidase-conjugated secondary antibody, diluted in blocking buffer (1:1000 goat anti-mouse or 1:2000 swine anti-rabbit; Dako Corporation, A/S, Denmark). Finally, the membranes were washed in TBST, developed using enhanced chemiluminescence (ECL) (Amersham Biosciences, Bucks, UK) and exposed to hyperfilm-ECL (Amersham Biosciences).

\section{Analysis of JNK and NF-KB phosphorylation}

Cells were seeded and grown in $60-\mathrm{mm}$ petri dishes as described above. After an incubation period of 1, 3, 6 or
$24 \mathrm{~h}$, the cells were scraped in PBS and centrifuged. The pellet was then resuspended in the lysis solution of the Bio-Plex Cell Lysis Kit (Bio-Rad) and frozen at $-20^{\circ} \mathrm{C}$. The samples were then thawed and centrifuged at $4500 \mathrm{~g}$ for $20 \mathrm{~min}$ at $4^{\circ} \mathrm{C}$, and the supernatant was collected. The lysate protein concentration was determined using the Bradford method (Protein Assay; Bio-Rad) with bovine serum albumin (Sigma-Aldrich) as standard, followed by addition of an equal volume of assay buffer from the BioPlex phoshpoprotein detection kit (Bio-Rad). The samples were frozen in $-20^{\circ} \mathrm{C}$ until determination of the amount of phosphorylated JNK (T183/Y185) or NF-kB p65 (S536) using Luminex technology on a Bio-Plex Suspension Array System (Bio-Rad) with the Bio-Plex phoshpoprotein detection kit (Bio-Plex, Bio-Rad) according to the manufacturer's instructions.

\section{Prostaglandin $\mathrm{E}_{2}$ determination}

The amount of $\mathrm{PGE}_{2}$ in the culture media was determined using Luminex technology on a Bio-Plex Suspension Array System (Bio-Rad) using a commercially available enzyme immunoassay (EIA) kit (Cayman), and a conventional EIA kit (Cayman).

\section{Statistics for non-microarray analyses}

All non-microarray experiments were analyzed in triplicates and reproducible data representing one of at least three independent experiments is demonstrated. Results are expressed as the mean \pm s.d. Student's $t$ test (twotailed) was used in the statistical analysis and $p$ values less than 0.05 were considered statistically significant.

\section{Additional material}

Additional file 1 List of differentially expressed genes at $1 \mathrm{~h}$ of TNFa stimulation. Genes that were differentially expressed in gingival fibroblasts due to TNFa treatment at the $1 \mathrm{~h}$ time point.

Additional file 2 List of significant Gene Ontology (GO) categories at $\mathbf{1} \mathbf{h}$ of TNFa stimulation. Significant GO categories due to TNFa stimulation at the $1 \mathrm{~h}$ time point, containing the name and number of each GO category for reference to the different worksheets of Additional file 3.

Additional file 3 Complete lists of differentially expressed genes in the significant $\mathrm{GO}$ categories at $1 \mathrm{~h}$ of TNFa stimulation. The differentially expressed genes of each significant GO category are listed on a separate worksheet, labeled with the $\mathrm{GO}$ category number.

Additional file $\mathbf{4}$ List of differentially expressed genes between 1 and $\mathbf{3} \mathbf{h}$ of TNFa stimulation. Genes that were differentially expressed in gingival fibroblasts due to TNFa treatment between the $1 \mathrm{~h}$ and $3 \mathrm{~h}$ time points. Additional file 5 List of significant Gene Ontology (GO) categories between 1 and $3 \mathrm{~h}$ of TNFa stimulation. Significant GO categories due to TNFa stimulation between the $1 \mathrm{~h}$ and $3 \mathrm{~h}$ time points, containing the name and number of each $\mathrm{GO}$ category for reference to the different worksheets of Additional file 6 .

Additional file 6 Complete lists of differentially expressed genes in the significant $\mathrm{GO}$ categories between 1 and $3 \mathrm{~h}$ of TNFa stimulation. The differentially expressed genes of each significant $\mathrm{GO}$ category are listed on a separate worksheet, labeled with the GO category number. 


\begin{abstract}
Additional file $\mathbf{7}$ List of differentially expressed genes between $\mathbf{3}$ and $6 \mathrm{~h}$ of TNFa stimulation. Genes that were differentially expressed in gingival fibroblasts due to TNFa treatment between the $3 \mathrm{~h}$ and $6 \mathrm{~h}$ time points. Additional file 8 List of significant Gene Ontology (GO) categories between 3 and $6 \mathrm{~h}$ of TNFa stimulation. Significant GO categories due to TNFa stimulation between the $3 \mathrm{~h}$ and $6 \mathrm{~h}$ time points, containing the name and number of each $\mathrm{GO}$ category for reference to the different worksheets of Additional file 9 .

Additional file 9 Complete lists of differentially expressed genes in the significant $\mathrm{GO}$ categories between 3 and $\mathbf{6} \mathrm{h}$ of TNFa stimulation. The differentially expressed genes of each significant $\mathrm{GO}$ category are listed on a separate worksheet, labeled with the $\mathrm{GO}$ category number.

Additional file 10 KTH HUM 34k Oligo Microarray. Additional information concerning the oligonucleotide microarray used in this study.

Additional file 11 Oligo Microarray genelist. Genelist for the oligonucleotide microarray, including probe sequences and accession numbers.
\end{abstract}

\section{Authors' contributions}

TB participated in conceiving and designing the study, carried out all experimental work and drafted the manuscript. JLi performed the microarray and bioinformatic data analyses and participated in manuscript drafting and study design. JLu participated in designing the study and in editing the manuscript. TM participated in manuscript editing and scientific discussions. TL participated in conceiving and designing the study, as well as in manuscript drafting and editing. All authors read and approved the final manuscript.

\section{Acknowledgements}

This work has been supported by grants from the Swedish Research Council, project no. 73XD-15005, Knut och Alice Wallenberg Foundation, the Swedish Patent Revenue Fund, and Karolinska Institutet.

\section{Author Details}

'Division of Pediatric Dentistry, Department of Dental Medicine, Karolinska Institutet, Huddinge, Sweden and 2School of Biotechnology, Department of Gene Technology, AlbaNova University Center, Royal Institute of Technology, Stockholm, Sweden

Received: 22 October 2009 Accepted: 15 April 2010

Published: 15 April 2010

\section{References}

1. Bascones A, Noronha S, Gomez M, Mota P, Gonzalez Moles MA, Dorrego MV: Tissue destruction in periodontitis: bacteria or cytokines fault? Quintessence Int 2005, 36:299-306.

2. Page RC, Offenbacher S, Schroeder HE, Seymour GJ, Kornman KS: Advances in the pathogenesis of periodontitis: summary of developments, clinical implications and future directions. Periodontol 2000 1997, 14:216-248.

3. Pihlstrom BL, Michalowicz BS, Johnson NW: Periodontal diseases. Lancet 2005, 366:1809-1820.

4. Yucel-Lindberg T, Nilsson S, Modeer T: Signal transduction pathways involved in the synergistic stimulation of prostaglandin production by interleukin-1 beta and tumor necrosis factor alpha in human gingival fibroblasts. J Dent Res 1999, 78:61-68.

5. Noguchi K, Ishikawa I: The roles of cyclooxygenase-2 and prostaglandin E2 in periodontal disease. Periodontol 2000 2007, 43:85-101.

6. Dewhirst FE, Moss DE, Offenbacher S, Goodson JM: Levels of prostaglandin E2, thromboxane, and prostacyclin in periodontal tissues. J Periodontal Res 1983, 18:156-163.

7. Preshaw PM, Heasman PA: Prostaglandin E2 concentrations in gingival crevicular fluid: observations in untreated chronic periodontitis. J Clin Periodontol 2002, 29:15-20.

8. Saegusa M, Murakami M, Nakatani Y, Yamakawa K, Katagiri M, Matsuda K, Nakamura K, Kudo I, Kawaguchi H: Contribution of membraneassociated prostaglandin E2 synthase to bone resorption. J Cell Physiol 2003, 197:348-356.

9. Tsai CC, Hong YC, Chen CC, Wu YM: Measurement of prostaglandin E2 and leukotriene B4 in the gingival crevicular fluid. J Dent 1998, 26:97-103.
10. Williams RC, Jeffcoat MK, Howell TH, Rolla A, Stubbs D, Teoh KW, Reddy MS, Goldhaber P: Altering the progression of human alveolar bone loss with the non-steroidal anti-inflammatory drug flurbiprofen. J Periodontol 1989, 60:485-490.

11. Jeffcoat MK, Page R, Reddy M, Wannawisute A, Waite P, Palcanis K, Cogen R, Williams RC, Basch C: Use of digital radiography to demonstrate the potential of naproxen as an adjunct in the treatment of rapidly progressive periodontitis. J Periodontal Res 1991, 26:415-421.

12. Graves DT, Cochran D: The contribution of interleukin-1 and tumor necrosis factor to periodontal tissue destruction. J Periodontol 2003, 74:391-401.

13. Assuma R, Oates T, Cochran D, Amar S, Graves DT: IL-1 and TNF antagonists inhibit the inflammatory response and bone loss in experimental periodontitis. J Immuno/ 1998, 160:403-409.

14. Gaspersic R, Stiblar-Martincic D, Osredkar J, Skaleric U: Influence of subcutaneous administration of recombinant TNF-alpha on ligatureinduced periodontitis in rats. J Periodontal Res 2003, 38:198-203.

15. Pers JO, Saraux A, Pierre R, Youinou P: Anti-TNF-alpha immunotherapy is associated with increased gingival inflammation without clinical attachment loss in subjects with rheumatoid arthritis. J Periodontol 2008, 79:1645-1651.

16. Rosenstein ED, Weissmann G, Greenwald RA: Porphyromonas gingivalis, periodontitis and rheumatoid arthritis. Med Hypotheses 2009, 73:457-458.

17. Soory M: Periodontal diseases and rheumatoid arthritis: a coincident model for therapeutic intervention? Curr Drug Metab 2007, 8:750-757.

18. Gartlehner G, Hansen RA, Jonas BL, Thieda P, Lohr KN: The comparative efficacy and safety of biologics for the treatment of rheumatoid arthritis: a systematic review and metaanalysis. J Rheumatol 2006 33:2398-2408

19. Yucel-Lindberg T, Olsson T, Kawakami T: Signal pathways involved in the regulation of prostaglandin E synthase-1 in human gingival fibroblasts. Cell Signal 2006, 18:2131-2142.

20. Bingham CO, Austen KF: Phospholipase A2 enzymes in eicosanoid generation. Proc Assoc Am Physicians 1999, 111:516-524.

21. Needleman P: Characterization of the reaction sequence involved in phospholipid labeling and deacylation and prostaglandin synthesis and actions. J Allergy Clin Immunol 1978, 62:96-102.

22. Smith WL, Song I: The enzymology of prostaglandin endoperoxide $H$ synthases-1 and -2. Prostaglandins Other Lipid Mediat 2002, 6869:115-128

23. Murakami M, Nakatani Y, Tanioka T, Kudo I: Prostaglandin E synthase. Prostaglandins Other Lipid Mediat 2002, 68-69:383-399.

24. Park JY, Pillinger MH, Abramson SB: Prostaglandin E2 synthesis and secretion: the role of PGE2 synthases. Clin Immunol 2006, 119:229-240

25. Jakobsson PJ, Thoren S, Morgenstern R, Samuelsson B: Identification of human prostaglandin E synthase: a microsomal, glutathionedependent, inducible enzyme, constituting a potential novel drug target. Proc Natl Acad Sci USA 1999, 96:7220-7225.

26. Tanikawa N, Ohmiya Y, Ohkubo H, Hashimoto K, Kangawa K, Kojima M, Ito $S$, Watanabe K: Identification and characterization of a novel type of membrane-associated prostaglandin E synthase. Biochem Biophys Res Commun 2002, 291:884-889.

27. Tanioka T, Nakatani Y, Semmyo N, Murakami M, Kudo I: Molecular identification of cytosolic prostaglandin E2 synthase that is functionally coupled with cyclooxygenase- 1 in immediate prostaglandin E2 biosynthesis. J Biol Chem 2000, 275:32775-32782

28. Watanabe K, Kurihara K, Tokunaga Y, Hayaishi O: Two types of microsomal prostaglandin E synthase: glutathione-dependent and independent prostaglandin E synthases. Biochem Biophys Res Commun 1997, 235:148-152.

29. Watanabe K, Kurihara K, Suzuki T: Purification and characterization of membrane-bound prostaglandin $E$ synthase from bovine heart. Biochim Biophys Acta 1999, 1439:406-414.

30. Bage T, Modeer T, Kawakami T, Quezada HC, Yucel-Lindberg T: Regulation of prostaglandin E synthases: effects of siRNA-mediated inhibition of microsomal prostaglandin E synthase-1. Biochim Biophys Acta 2007, 1773:1589-1598.

31. Yucel-Lindberg T, Hallstrom T, Kats A, Mustafa M, Modeer T: Induction of microsomal prostaglandin $\mathrm{E}$ synthase-1 in human gingival fibroblasts. Inflammation 2004, 28:89-95. 
32. Devaux Y, Seguin C, Grosjean S, de Talance N, Camaeti V, Burlet A, Zannad F, Meistelman C, Mertes PM, Longrois D: Lipopolysaccharide-induced increase of prostaglandin $\mathrm{E}(2)$ is mediated by inducible nitric oxide synthase activation of the constitutive cyclooxygenase and induction of membrane-associated prostaglandin E synthase. J Immunol 2001, 167:3962-3971.

33. Gudis K, Tatsuguchi A, Wada K, Futagami S, Nagata K, Hiratsuka T, Shinji Y, Miyake K, Tsukui T, Fukuda Y, Sakamoto C: Microsomal prostaglandin E synthase (mPGES)-1, mPGES-2 and cytosolic PGES expression in human gastritis and gastric ulcer tissue. Lab Invest 2005, 85:225-236.

34. Mustafa M, Wondimu B, Yucel-Lindberg T, Kats-Hallstrom AT, Jonsson AS, Modeer T: Triclosan reduces microsomal prostaglandin E synthase-1 expression in human gingival fibroblasts. J Clin Periodontol 2005, 32:6-11.

35. Cheng S, Afif H, Martel-Pelletier J, Pelletier JP, Li X, Farrajota K, Lavigne M, Fahmi H: Activation of peroxisome proliferator-activated receptor gamma inhibits interleukin-1 beta-induced membrane-associated prostaglandin E2 synthase-1 expression in human synovial fibroblasts by interfering with Egr-1. J Biol Chem 2004, 279:22057-22065.

36. Giannico G, Mendez M, LaPointe MC: Regulation of the membranelocalized prostaglandin E synthases mPGES-1 and mPGES-2 in cardiac myocytes and fibroblasts. Am J Physiol Heart Circ Physiol 2005, 288:H165-174.

37. van Rees BP, Sivula A, Thoren S, Yokozaki H, Jakobsson PJ, Offerhaus GJ, Ristimaki A: Expression of microsomal prostaglandin E synthase-1 in intestinal type gastric adenocarcinoma and in gastric cancer cell lines. Int J Cancer 2003, 107:551-556.

38. Subbaramaiah K, Yoshimatsu K, Scherl E, Das KM, Glazier KD, Golijanin D, Soslow RA, Tanabe T, Naraba H, Dannenberg AJ: Microsomal prostaglandin E synthase-1 is overexpressed in inflammatory bowel disease. Evidence for involvement of the transcription factor Egr-1. J Biol Chem 2004, 279:12647-12658.

39. Han R, Tsui S, Smith TJ: Up-regulation of prostaglandin E2 synthesis by interleukin-1 beta in human orbital fibroblasts involves coordinate induction of prostaglandin-endoperoxide $\mathrm{H}$ synthase-2 and glutathione-dependent prostaglandin E2 synthase expression. J Biol Chem 2002, 277:16355-16364.

40. Flavell SJ, Hou TZ, Lax S, Filer AD, Salmon M, Buckley CD: Fibroblasts as novel therapeutic targets in chronic inflammation. Br J Pharmaco/ 2007, 153(Suppl 1):S241-246.

41. Heath JK, Atkinson SJ, Hembry RM, Reynolds JJ, Meikle MC: Bacterial antigens induce collagenase and prostaglandin E2 synthesis in human gingival fibroblasts through a primary effect on circulating mononuclear cells. Infect Immun 1987, 55:2148-2154.

42. Kornman KS, Page RC, Tonetti MS: The host response to the microbial challenge in periodontitis: assembling the players. Periodonto/ 2000 1997, 14:33-53.

43. Meikle MC, Hembry RM, Holley J, Horton C, McFarlane CG, Reynolds JJ: Immunolocalization of matrix metalloproteinases and TIMP-1 (tissue inhibitor of metalloproteinases) in human gingival tissues from periodontitis patients. J Periodontal Res 1994, 29:118-126.

44. Reynolds JJ, Meikle MC: Mechanisms of connective tissue matrix destruction in periodontitis. Periodontol 2000 1997, 14:144-157.

45. Glonek GF, Solomon PJ: Factorial and time course designs for cDNA microarray experiments. Biostatistics 2004, 5:89-111.

46. Hacker H, Karin M: Regulation and function of IKK and IKK-related kinases. SCiSTKE 2006, 2006:re13.

47. Bennett BL, Sasaki DT, Murray BW, O'Leary EC, Sakata ST, Xu W, Leisten JC, Motiwala A, Pierce S, Satoh Y, et al:: SP60 an anthrapyrazolone inhibitor of Jun N-terminal kinase. Proc Natl Acad Sci USA 0125, 98:13681-13686.

48. Pierce JW, Schoenleber R, Jesmok G, Best J, Moore SA, Collins T, Gerritsen ME: Novel inhibitors of cytokine-induced IkappaBalpha phosphorylation and endothelial cell adhesion molecule expression show anti-inflammatory effects in vivo. J Biol Chem 1997, 272:21096-21103

49. Swinney DC, Xu YZ, Scarafia LE, Lee I, Mak AY, Gan QF, Ramesha CS, Mulkins MA, Dunn J, So OY, et al:: A small molecule ubiquitination inhibitor blocks NF-kappa B-dependent cytokine expression in cells and rats. $J$ Biol Chem 2002, 277:23573-23581.

50. Kojima F, Naraba H, Miyamoto S, Beppu M, Aoki H, Kawai S: Membraneassociated prostaglandin E synthase- 1 is upregulated by proinflammatory cytokines in chondrocytes from patients with osteoarthritis. Arthritis Res Ther 2004, 6:R355-365.

51. Stichtenoth DO, Thoren S, Bian H, Peters-Golden M, Jakobsson PJ, Crofford $\mathrm{LJ}$ : Microsomal prostaglandin $\mathrm{E}$ synthase is regulated by proinflammatory cytokines and glucocorticoids in primary rheumatoid synovial cells. J Immunol 2001, 167:469-474

52. Alexander D, Friedrich B, Abruzzese T, Gondolph-Zink B, Wulker N, Aicher WK: The active form of leflunomide, HMR facilitates TNF-alpha and IL17 induced MMP-1 and MMP-3 expression. Cell Physiol Biochem 2006, 17:69-78.

53. Shen F, Ruddy MJ, Plamondon P, Gaffen SL: Cytokines link osteoblasts and inflammation: microarray analysis of interleukin-17- and TNFalpha-induced genes in bone cells. J Leukoc Biol 2005, 77:388-399.

54. Tian B, Nowak DE, Brasier AR: A TNF-induced gene expression program under oscillatory NF-kappaB control. BMC Genomics 2005, 6:137.

55. Zer C, Sachs G, Shin JM: Identification of genomic targets downstream of p38 mitogen-activated protein kinase pathway mediating tumor necrosis factor-alpha signaling. Physio/ Genomics 2007, 31:343-351.

56. Zhang HG, Hyde K, Page GP, Brand JP, Zhou J, Yu S, Allison DB, Hsu HC, Mountz JD: Novel tumor necrosis factor alpha-regulated genes in rheumatoid arthritis. Arthritis Rheum 2004, 50:420-431.

57. Papapanou PN, Abron A, Verbitsky M, Picolos D, Yang J, Qin J, Fine JB, Pavlidis P: Gene expression signatures in chronic and aggressive periodontitis: a pilot study. Eur J Oral Sci 2004, 112:216-223.

58. Beikler T, Peters U, Prior K, Eisenacher M, Flemmig TF: Gene expression in periodontal tissues following treatment. BMC Med Genomics 2008, 1:30.

59. Sorensen LK, Havemose-Poulsen A, Sonder SU, Bendtzen K, Holmstrup P. Blood cell gene expression profiling in subjects with aggressive periodontitis and chronic arthritis. J Periodonto/ 2008, 79:477-485.

60. Wang PL, Ohura K, Fujii T, Oido-Mori M, Kowashi Y, Kikuchi M, Suetsugu Y, Tanaka J: DNA microarray analysis of human gingival fibroblasts from healthy and inflammatory gingival tissues. Biochem Biophys Res Commun 2003, 305:970-973.

61. Vardar-Sengul S, Arora S, Baylas H, Mercola D: Expression profile of human gingival fibroblasts induced by interleukin-1 beta reveals central role of nuclear factor-kappa B in stabilizing human gingival fibroblasts during inflammation. J Periodontol 2009, 80:833-849.

62. Degousee N, Angoulvant D, Fazel S, Stefanski E, Saha S, Iliescu K, Lindsay TF, Fish JE, Marsden PA, Li RK, et al:: c-Jun N-terminal kinase-mediated stabilization of microsomal prostaglandin E2 synthase-1 mRNA regulates delayed microsomal prostaglandin E2 synthase-1 expression and prostaglandin E2 biosynthesis by cardiomyocytes. J Biol Chem 2006, 281:16443-16452.

63. Moon Y, Glasgow WC, Eling TE: Curcumin suppresses interleukin 1betamediated microsomal prostaglandin E synthase 1 by altering early growth response gene 1 and other signaling pathways. J Pharmacol Exp Ther 2005, 315:788-795.

64. Chen CC, Sun YT, Chen JJ, Chang YJ: Tumor necrosis factor-alphainduced cyclooxygenase-2 expression via sequential activation of ceramide-dependent mitogen-activated protein kinases, and IkappaB kinase 1/2 in human alveolar epithelial cells. Mol Pharmacol 2001, 59:493-500.

65. Wadleigh DJ, Herschman HR: Transcriptional regulation of the cyclooxygenase-2 gene by diverse ligands in murine osteoblasts. Biochem Biophys Res Commun 1999, 264:865-870.

66. Nieminen R, Lahti A, Jalonen U, Kankaanranta H, Moilanen E: JNK inhibitor SP600125 reduces COX-2 expression by attenuating mRNA in activated murine J774 macrophages. Int Immunopharmacol 2006, 6:987-996.

67. Nieminen R, Leinonen S, Lahti A, Vuolteenaho K, Jalonen U, Kankaanranta $\mathrm{H}$, Goldring MB, Moilanen E: Inhibitors of mitogen-activated protein kinases downregulate COX-2 expression in human chondrocytes. Mediators Inflamm 2005, 2005:249-255

68. Zhang $\mathrm{X}$, Neufeld $\mathrm{AH}$ : Signal transduction pathways for epidermal growth factor stimulated cyclooxygenase-2 induction in astrocytes. Exp Eye Res 2007, 85:280-288

69. Han Z, Boyle DL, Aupperle KR, Bennett B, Manning AM, Firestein GS: Jun Nterminal kinase in rheumatoid arthritis. J Pharmacol Exp Ther 1999, 291:124-130.

70. Mitsuyama K, Suzuki A, Tomiyasu N, Tsuruta O, Kitazaki S, Takeda T, Satoh Y, Bennett BL, Toyonaga A, Sata M: Pro-inflammatory signaling by Jun-Nterminal kinase in inflammatory bowel disease. Int J Mol Med 2006, 17:449-455. 
71. Han Z, Boyle DL, Chang L, Bennett B, Karin M, Yang L, Manning AM, Firestein GS: c-Jun N-terminal kinase is required for metalloproteinase expression and joint destruction in inflammatory arthritis. J Clin Invest 2001, 108:73-81.

72. Han Z, Chang L, Yamanishi Y, Karin M, Firestein GS: Joint damage and inflammation in c-Jun $\mathrm{N}$-terminal kinase 2 knockout mice with passive murine collagen-induced arthritis. Arthritis Rheum 2002, 46:818-823.

73. Catley MC, Chivers JE, Cambridge LM, Holden N, Slater DM, Staples KJ, Bergmann MW, Loser P, Barnes PJ, Newton R: IL-1beta-dependent activation of NF-kappaB mediates PGE2 release via the expression of cyclooxygenase- 2 and microsomal prostaglandin E synthase. FEBS Lett 2003, 547:75-79.

74. Kuldo JM, Westra J, Asgeirsdottir SA, Kok RJ, Oosterhuis K, Rots MG, Schouten JP, Limburg PC, Molema G: Differential effects of NF-\{kappa\}B and p38 MAPK inhibitors and combinations thereof on TNF-\{alpha\}and IL-1 \{beta\}-induced proinflammatory status of endothelial cells in vitro. Am J Physiol Cell Physiol 2005, 289:C1229-1239.

75. Park MH, Song HS, Kim KH, Son DJ, Lee SH, Yoon DY, Kim Y, Park IY, Song S, Hwang BY, et al:: Cobrotoxin inhibits NF-kappa B activation and target gene expression through reaction with NF-kappa B signal molecules. Biochemistry 2005, 44:8326-8336.

76. Barakat W, Herrmann O, Baumann B, Schwaninger M: NF-kappaB induces PGE2-synthesizing enzymes in neurons. Naunyn Schmiedebergs Arch Pharmacol 2009, 380:153-160.

77. Casas J, Meana C, Esquinas E, Valdearcos M, Pindado J, Balsinde J, Balboa MA: Requirement of JNK-mediated phosphorylation for translocation of group IVA phospholipase A2 to phagosomes in human macrophages. J Immunol 2009, 183:2767-2774.

78. Yucel-Lindberg T, Ahola H, Carlstedt-Duke J, Modeer T: Induction of Cytosolic Phospholipase A2 mRNA Expression by Interleukin-1 $\beta$ and Tumor Necrosis Factor a in Human Gingival Fibroblasts. Inflammation 2000, 24:207-217

79. Murakami M, Naraba H, Tanioka T, Semmyo N, Nakatani Y, Kojima F, Ikeda T, Fueki M, Ueno A, Oh S, Kudo I: Regulation of prostaglandin E2 biosynthesis by inducible membrane-associated prostaglandin E2 synthase that acts in concert with cyclooxygenase-2. J Biol Chem 2000, 275:32783-32792

80. Lindberg J, af Klint E, Ulfgren AK, Stark A, Andersson T, Nilsson P, Klareskog $L$, Lundeberg J: Variability in synovial inflammation in rheumatoid arthritis investigated by microarray technology. Arthritis Res Ther 2006, 8:R47.

81. KTH microarray core facility homepage [http://www.ktharray.se

82. Maglott D, Ostell J, Pruitt KD, Tatusova T: Entrez Gene: gene-centered information at NCBI. Nucleic Acids Res 2007, 35:D26-31.

83. R: A language and environment for statistical computing [http:// www.R-project.org]

84. Gentleman RC, Carey VJ, Bates DM, Bolstad B, Dettling M, Dudoit S, Ellis B, Gautier L, Ge Y, Gentry J, et al: Bioconductor: open software development for computational biology and bioinformatics. Genome Biol 2004, 5:R80

85. Yang YH, Dudoit S, Luu P, Lin DM, Peng V, Ngai J, Speed TP: Normalization for CDNA microarray data: a robust composite method addressing single and multiple slide systematic variation. Nucleic Acids Res 2002, 30:e15.

86. Smyth GK: Linear models and empirical bayes methods for assessing differential expression in microarray experiments. Stat App/ Genet Mol Biol 2004, 3:Article3.

87. Reiner A, Yekutieli D, Benjamini Y: Identifying differentially expressed genes using false discovery rate controlling procedures. Bioinformatics 2003, 19:368-375.

88. Ashburner M, Ball CA, Blake JA, Botstein D, Butler H, Cherry JM, Davis AP, Dolinski K, Dwight SS, Eppig JT, et al.: Gene ontology: tool for the unification of biology. The Gene Ontology Consortium. Nat Genet 2000, 25:25-29.

89. Falcon S, Gentleman R: Using GOstats to test gene lists for GO term association. Bioinformatics 2007, 23:257-258.

90. Barrett T, Troup DB, Wilhite SE, Ledoux P, Rudnev D, Evangelista C, Kim IF, Soboleva A, Tomashevsky M, Edgar R: NCBI GEO: mining tens of millions of expression profiles--database and tools update. Nucleic Acids Res 2007, 35:D760-765.

91. Wain HM, Lush M, Ducluzeau F, Povey S: Genew: the human gene nomenclature database. Nucleic Acids Res 2002, 30:169-171. doi: 10.1186/1471-2164-11-241

Cite this article as: Båge et al., Signal pathways JNK and NF-?B, identified by global gene expression profiling, are involved in regulation of TNF?-induced mPGES-1 and COX-2 expression in gingival fibroblasts BMC Genomics 2010,

$11: 241$

\section{Submit your next manuscript to BioMed Central} and take full advantage of:

- Convenient online submission

- Thorough peer review

- No space constraints or color figure charges

- Immediate publication on acceptance

- Inclusion in PubMed, CAS, Scopus and Google Scholar

- Research which is freely available for redistribution 